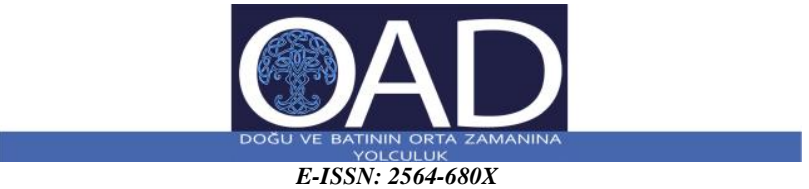

Aralık 2021 / December 2021

Yıl 4, Sayı 2 / Year 4, Issue 2

ATIF BILGGISI / REFERENCE INFORMATION

ÇELIK, Siren, “II. Manuel Palaiologos’un Selaniklilere Tavsiye Söylevi: 1383-1387 Osmanlı Selanik Kuşatmasına Dair Bir Metin”, Ortaçă̆ Araştırmaları Dergisi, IV/II, Aralık 2021, s. 177-189.

Makale Türü: Tarih Araștırma

DOI No: https://doi.org/10.48120/oad.996455

\title{
II. Manuel Palaiologos’un Selaniklilere Tavsiye Söylevi: 1383-1387 Osmanlı Selanik Kuşatmasına Dair Bir Metin
}

\section{Siren ÇELIK ${ }^{1 *+}$}

${ }^{1}$ Dr. Öğr. Üyesi, Marmara Üniversitesi, Fen-Edebiyat Fakültesi, Tarih Bölümü, İSTANBUL.

*sirencelik@gmail.com

${ }^{+}$ORCID: 0000-0001-9138-8810

$\ddot{\boldsymbol{O}}_{\boldsymbol{z}}-\mathrm{Bu}$ makale Bizans imparatoru II. Manuel Palaiologos'un (1350-1425) tahta çıkmadan önce, Selanik yöneticisiyken yazdığı bir söylevi incelemektedir. 1382-1387 yılları arasında Selanik'i babası V. Ioannes'ten bağımsız bir şekilde yöneten Manuel, aynı zamanda onun Osmanlılara karşı uzlaşmacı tutumunu reddetmiş ve onlarla çatışmaya girmiştir. Bu nedenle, Selanik 1383 senesinde Sultan I. Murad'ın emriyle kuşatılmıştır. Manuel, bilhassa Osmanlılara direnmek istemeyen ve haraç ödeme yanlısı olan bazı Selaniklileri savaşmaya ikna etmek üzere Selaniklilere Tavsiye Söylevi eserini kaleme almış ve icra etmiştir. Ağır bir Attika Yunancasıyla yazılmış olan söylev çok az çalışılmıştır, ancak hem içerdiği tarihi bilgiler bakımından hem de edebi nitelikleri nedeniyle oldukça dikkat çekicidir. Söylev Yunanca aslından okunabilmektedir, bildiğimiz kadarıyla henüz modern bir dile çevirisi yoktur. Bu makale Selaniklilere Tavsiye Söylevi’nin Türkçe çevirisini ve eserin ilk detaylı incelemesini içerecektir. Makale, sırasıyla Manuel'in Selanik’teki yönetimini, söylevin yazım ve icrasını, temalarını ve edebi özelliklerini tartıştıktan sonra eserin Yunanca aslından çevirisini dipnotlarda verilen açıklamalar eşliğinde sunacaktır.

Anahtar Kelimeler- Bizans-Osmanlı İlişkileri, II. Manuel, Selanik, Bizans Edebiyatı, Söylev.

The Advisory Discourse to the Thessalonians of Manuel II Palaiologos: A Text on the Ottoman siege of Thessalonike between 13831387

\begin{abstract}
This article discusses an oration written by the Byzantine Emperor Manuel II Palaiologos (1350-1425) as the ruler of Thessalonike prior to his accession. While governing Thessalonike between 1383-1387 independently from his father John V, Manuel refused his father's policy of reconciliation towards the Ottomans and instead, entered into military conflicts with them. As an outcome of Manuel's policy, Thessalonike was besieged in 1383 on the orders of the Ottoman Sultan Murad I. Manuel wrote and performed the Advisory Discourse to the Thessalonians in order to persuade the Thessalonians to fight aganist the Ottomans, targeting particularly those citizens who inclined towards surrendering and paying tribute to the Ottomans. The oration, composed in a rather difficult Attic Greek is understudied, yet it is noteworthy on the account of the historical information it offers, as well of its literary aspects. This article offers a translation of the Advisory Discourse to the Thessalonians into Turkish and the first in-depth study of the oration. This article will discuss in sequence Manuel's rule in Thessalonike, the composition and the performance of the oration, its themes and literary aspects. Finally, the article will offer a Turkish translation of the oration, accompanied by extensive notes.
\end{abstract}

Keywords - Byzantine-Ottoman Relations, Manuel II Palaiologos, Thessalonike, Byzantine Literature, Oration. 
Son Bizans imparatorlarından II. Manuel Palaiologos (1350-1425) yaşadığı döneme damga vurmuş, oldukça çalkantılı bir hayat sürmüştür. ${ }^{1}$ Aynı zamanda üretken bir yazar olan Manuel edebi, felsefi ve teolojik eserlerden oluşan kapsamlı bir külliyat bırakmıştır. Eserleri söylevler, şiir, mektup, vaaz, retorik alıştırmalar, diyaloglar, felsefi ve teolojik çalışmalar gibi geniş bir yelpazeye sahiptir. Manuel, tahta çıkmadan önce bile pek çok siyasi sorunla boğuşmuş, Selanik'in yöneticisi olmuş, imparatorluğun Osmanlılar karşısında giderek küçülmesine, babası, ağabeyi ve yeğeni arasındaki tah mücadelelerine tanık olmuştur. ${ }^{2} 1391$ 'de imparator olduktan sonra da çeşitli siyasi, ekonomik ve sosyal sorunlarla mücadele etmiş, 1425 'teki ölümüne dek Konstantinopolis Osmanlılar tarafindan üç kez kuşatılmıştır. $\quad(1394-1402, \quad 1411, \quad 1423)$ I. Bayezid'ın Konstantinopolis'i sekiz sene sürecek bir ablukaya alması karşısında Manuel Avrupalı devletlerden yardım istemiş, 1399 yılında da bizzat Avrupa'ya giderek 1403'e kadar çeşitli İtalya şehirlerinde, Fransa ve İngiltere'de bulunmuştur. Bu kuşatmalar dışında da Osmanlılarla sıklıkla karşı karşıya kalan Manuel, 1391/92'de I. Bayezid'in yanında Anadolu'da sefere çıkmak zorunda kalmış, ordu Ankara'ya çekilince burada önemli bir İslam alimiyle İslam ve Hristiyanlık hakkında ilmi tartışmalar yapmıştır. Bu sohbetleri daha sonra Bir Pers ile Diyalog olarak bilinen bir eserde ölümsüzleştirmiştir. ${ }^{3} \mathrm{Bu}$ eserin yanı sıra imparatorun mektupları ve kardeşi Mora Despotu Theodoros için yazdığı cenaze söylevi de Manuel'in Osmanlılarla olan ilişkileri hakkında önemli bilgiler içerir. ${ }^{4}$ Manuel'in Osmanlıları tasviri özellikle Sultan Bayezid'1 - edebi yönden de oldukça ilgi çekicidir.

II. Manuel'in daha az bilinen ve az çalışılmış bir diğer eseri, Selaniklilere Tavsiye Söylevi, aslında imparatorun siyasi görüşleri ve Osmanlı-Bizans ilişkileri hakkında zengin bir malzeme barındırır. Manuel bu söylevi henüz tahta çıkmamışken, Selanik yöneticisi olarak, 1383 'de şehir Osmanlılar tarafından kuşatılmışken kaleme almıştır. 1369-1372 yılları arasında Selanik despotluğu yapan Manuel, ağabeyi IV. Andronikos'un isyan ederek gözden düşmesi üzerine 1373 'de veliaht ilan edilmiştir ve Konstantinopolis'te ikamet etmiştir. Bir iç savaş sonrasında babası V. Ioannes'in Andronikos'u tekrar veliaht tayin etmesi üzerine Manuel babasına gücenmiş, kendisinden onay almadan 1382'de Selanik'e gelerek șehri Konstantinopolis’ten bağımsız olarak yönetmeye başlamıştır. Üstelik

${ }^{1}$ II. Manuel'in hayatı ve hükümdarlığı için bakınız John W. Barker, Manuel II Palaeologus (1391-1425): A Study in Late Byzantine Statesmanship, Rutgers University Press, New Brunswick 1969 ve Siren Çelik, Manuel II Palaiologos (1350-1425): A Byzantine Emperor in a Time of Tumult, Cambridge University Press, New York, 2021.

2 Andronikos'un ayaklanması için bkz Franz Dölger, 'Zum Aufstand des Andronikos IV gegen seinen Vater Johannes V im Mai 1373', Revue des études byzantins 19, 1961, ss. 328-333; Raymond Joseph Loenertz, 'La première insurrection d'Andronic IV Paléologue (1373)', Echos d'Orient 38, 1939, ss. 334-345; Nilgün Elam, 'Babalar ve Oğullar: IV. Andronikos Palaiologos ve Savcı Çelebi'nin İsyanı (1373)', Tarih Araştırmaları Dergisi 30, 2011, ss. 29-74; Barker, Manuel II, ss. 19-24, Celik, Manuel II, ss. 62-72. 3 Elbette, sohbetleri yazıya dökerken imparator tartışmaları kendisi ve Hristiyanlık galip gelecek şekilde kurgulamıştır, diyalogu sohbetlerin bir dökümü değil de, yer yer kurguya başvuran edebi bir eser olarak kaleme almıştır. Dolayısıyla eserin 'gerçekliği' ve sohbetleri birebir yansıtması beklenmemelidir, bkz Siren Çelik, 'The emperor, the sultan and the scholar: the portrayal of the Ottomans in the Dialogue with a Persian of Manuel II Palaiologos', Byzantine and Modern Greek Studies 41, 2, 2017, ss. 208-228. Manuel'in sohbet ettiği alimin kimliği belirsizdir, ancak bu kişinin Hacı Bayram Veli olabileceğine dair görüşler vardır bkz; Michel Balivet, 'Le soufi et le basileus: Haci Bayram Veli et Manuel II Paléologue', Medievo Graeco 4, 2004, ss. 19-31

Eserin iki adet tam edisyonu vardır: Dialoge mit einem Perser, ed. Erich Trapp, Osterreichische Akademie der Wissenschaften, Viyana, 1966; Dialoge mit einem Muslim, 3 vols, ed. ve Almanca çev. Karl Förstel, Echter-Orlos Verlag, Würzburg, 1995.

4 Celik, Manuel II, imparatorun eserlerinde Osmanlları tasvirini ele almaktadır. Cenaze söylevi ve mektuplar için bkz Funeral Oration to His babasının Osmanlılara karşı izlediği uzlaşmacı tutumu reddetmiş ve onlara savaş açmıştır. Bunun sonucunda ise Osmanlılar 1383 senesinde Selanik'i kuşatmışlardır; şehir 1387'de teslim olmuştur.

Bu makale, Selanikliler için Tavsiye Söylevi'ni hem edebi yönden hem içerdiği önemli tarihi bilgiler yönünden inceleyecek, bu eserin ilk detaylı incelemesini sunacaktır. Makale, ilk olarak Manuel'in 1382-1387 yılları arasında Selanik’teki yönetimini ele alacak ve eserin arka planını tanıtacaktır. Daha sonra sırasıyla söylevin yazımını ve icrasını, edebi stilini, içerdiği temaları ve siyasi mesajları tartışacaktır. En son olarak, makale bu söylevin Yunanca aslından yapılmış Türkçe bir çevirisini, dipnotlarda verilecek açıklamalar eşliğinde sunacaktır.

\section{Manuel ve Selanik (1382-1387)}

II. Manuel, genç bir prens iken 1369-1372 yılları arasında Selanik despotluğu yapmıştır. ${ }^{6}$ Manuel'in hayatının bu dönemi hakkında çok az şey bilinmektedir. 1371'de borçlarını ödemeyen V. Ioannes Venedik'te mahsur kalınca Manuel Selanik'ten yola çıkarak babasının yanına gitmiş, beraberinde getirdiği para ile borçlarını ödemiştir. 1373'te ağabeyi IV. Andronikos isyan etmiş ve gözden düşmüştür, bunun üzerine Manuel veliaht prens olarak tayin edilmiş ve Konstantinopolis'te kalmıştır. 1376'da hapisten kaçan Andronikos tahtı ele geçirmiş, babası ve iki erkek kardeşini hapsetmiştir. 1379'da kaçmayı başaran Ioannes ve oğulları Osmanlılarından destek alarak Konstantinopolis'e girmişlerdir. Şehri kasıp kavuran bu iç savaş sonucunda 1381 'de Ioannes, oğlu Andronikos'u tekrar tahtın meşru varisi olarak kabul etmiş, Manuel konumunu kaybetmiştir. Duruma içerleyen Manuel 1382'nin başında, babasının rızası olmadan Selanik'e gelmiş ve burada bağımsız olarak hüküm sürmeye başlamıştır. ${ }^{7}$ Khalkokondyles'in verdiği kısa bilgi haricinde Bizans tarih yazarlarının bahsetmediği bu dönemin kaynakları, II. Manuel'in ve onun arkadaşı, hocası olan Demetrios Kydones'in mektuplarıyla Selanik metropoliti olan Isidoros Glabas'ın vaazlarıdır. ${ }^{8}$

Manuel'in 1382-1387 arasındaki Selanik hükümdarlı̆̆ı, 13691372 'deki yönetiminin aksine Konstantinopolis'e bağlı bir despotluk yönetim değildir. Aksine şehre imparatorun bilgisi ve onayı olmadan

Brother Theodore, ed. ve çev. Julian Chrysostomides, Association for Byzantine Studies, Selanik, 1985; The Letters of Manuel II Palaeologus, ed. ve çev. George T. Dennis, Dumbarton Oaks Research Library and Collection, Washington DC, 1977.

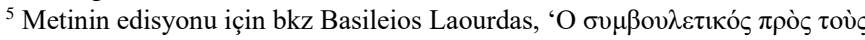

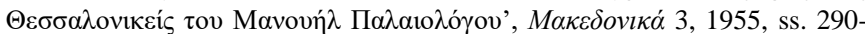
307. Çeviride bu edisyon kullanılmıştır.

${ }^{6} \mathrm{Bu}$ dönemin incelemesi için bkz Çelik, Manuel II, 55-62. Geç Bizans devrinde Selanik için ayrıca bkz Nevra Necipoğlu, 'The aristocracy in late Byzantine Thessalonike: a case study of the City's archontes (late 14th and early 15th centuries)', Dumbarton Oaks Papers 57, 2003, ss. 133-151; John W. Barker, 'Late Byzantine Thessalonike: a second city's challenges and responses', Dumbarton Oaks Papers 57, 2003, ss. 5-30.

${ }^{7}$ Manuel'in Selanik'teki bağımsız yönetimi için bkz George T. Dennis. The Reign of Manuel II Palaeologus in Thessalonica (1382-1387), Pontificum Institutum Orienatalium Studiorum, Roma, 1960 ve Çelik, Manuel II, ss. 77110. Makalenin bu kısmı, bu iki esere dayanarak yazılmıştır.

${ }^{8}$ The Letters of Manuel II Palaeologus; Démétrius Cydonès Correspondance, 2 vol, ed. Raymond Joseph Loenertz, Biblioteca Apostolica Vaticana, Roma, Vatikan, 1951-196); Laonikos Chalkokondlyles. The Histories, ed. ve çev. Anthony Kaldellis, Harvard University Press, Cambridge MA ve Londra,

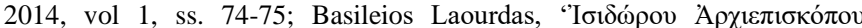

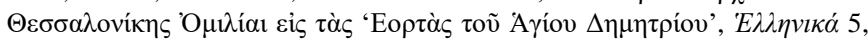

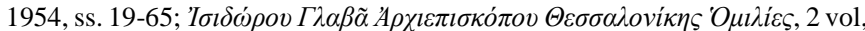
ed. Venizelos Christophorides, Ekdoseis Pournara, Selanik, 1992-1996;

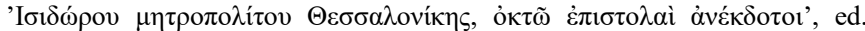

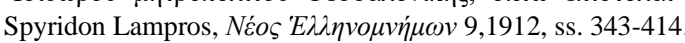


gelmiş, kendini bağımsız bir şehir hükümdarı olarak konumlandırmıştır. Daha da önemlisi babasının Osmanlılara karşı izlediği uzlaşmacı siyasetle alenen çelişerek Osmanlılara savaş açmıştır. Bu politikası başlı başına Konstantinopolis'e ve imparatora karşı bir başkaldırı olarak yorumlanabilir. ${ }^{9}$ İlk başlarda Osmanlılara karşı birkaç küçük zafer kazanan Manuel'in başarıları Konstantinopolis'ten taraftar toplamasinı ve Epiros Despotu Thomas Preljubović'in kendi otoritesini tanıması sağlamıştır. Kydones'in mektupları, Konstantinopolis'ten Selanik'e, Manuel'e katılmaya gelen bu kişilerin V. Ioannes'ten gizli bir şekilde geldiklerini ve imparatorun duruma son derece kızdığını gösterir. ${ }^{10}$ Kydones'in mektupları ayrıca Manuel'in Selanik'teki ilk aylarının iyimser atmosferini yansıtır. Kydones, bir mektubunda Manuel'in kazandığ 1 ganimetlerin Konstantinopolis'te halk arasında büyük heyecan yarattığını, pazar yerindeki dilencinin bile Selanik direnişine katılmayı düşündüğünü şaka yollu belirtir. ${ }^{11}$ Bir diğer mektubunda ise, anlamlı bir şekilde Selanik’ten 'yeni imparatorluk' ( $\dot{\eta}$ véa $\left.\beta \alpha \sigma i \lambda \varepsilon^{\prime \prime \alpha}\right)$ olarak bahseder. ${ }^{12}$

Manuel'in başarıları ve şehirdeki iyimser atmosfer çok kısa sürecektir. Manuel'in başkaldırısına karşılık olarak Osmanlı sultanı I. Murad, 1383 sonbaharında Hayrettin Paşa komutasındaki birliklere Selanik'i kuşattırır. Kuşatma, şehirde zaten var olan sosyal ve ekonomik problemleri daha da alevlendirir. ${ }^{13}$ Selanik'in yoksulları kuşatma nedeniyle daha da zor bir duruma düşerken, şehrin ileri gelenleri olan archontes savunmaya maddi olarak katkıda bulunmay ve yoksullara yardım etmeyi reddederler. Selanik, kuşatmanın daha ilk başlarında ciddi sıkıntılar çekmeye başlar. Manuel ve Kydones'in mektupları, halkın bu durumdan Manuel'i sorumlu tuttuğunu, şehrin büyük kısmının savaşmak yerine Osmanlılara teslim olmayı tercih ettiğini vurgular. Manuel, hem archontes hem yoksullar üzerine otorite kurmakta zorlanmaktadır. Manuel bir mektubunda, Selaniklileri özgürlükleri için savaşmaya ikna etmenin zorluğundan yakınır. ${ }^{14} \mathrm{Bu}$ ikna çabalarının bir parçası olarak 1383 'te Selaniklilere Tavsiye Söylevi'ni yazar ve bir topluluk önünde icra eder.

Bu söylev de Selaniklileri ikna konusunda başarılı olmaz. Isidoros Glabas'ın vaazları, Manuel'in şehre ek vergiler koyduğunu ve bu durumun büyük bir hoşnutsuzluk yarattığına dair önemli ipuçlar içerir. Glabas, 1srarla halk1 Manuel'e itaat etmeye çağırır, ancak kendisi de 1384'te Selanik'i terk eder. Muhtemelen, Manuel'in kilise mallarına el koyması nedeniyle yaşanılan tartışmalar sonucunda böyle bir karar almıştır. ${ }^{15}$ Glabas, şehrin Osmanlıların eline geçmesine kadar geri dönmeyecektir. Çaresiz kalan Manuel, toprak karşııı̆ı̆nda Venedik'ten yardım ister ancak talepleri kabul edilmez. ${ }^{16}$ Kardeşi Mora Despotu I. Theodoros ve Korinth Dükü Nerio Acciajuoli ile Osmanlılara karşı ittifak kurmasına rağmen yine de beklediği yardımı göremez. Son olarak papalıktan yardım isteyen Manuel karşılık olarak kiliselerin birleşmesi konusunda işbirliğine razı olur. ${ }^{17}$ Önce yanlışlıkla Konstantinopolis'e giden papalık heyeti sonra Selanik'e gelse de müzakerelerden bir sonuç alınamaz.

\footnotetext{
${ }^{9} 1373$ 'te veliaht tayin edilince kendisine verilen basileus (imparator) unvanın Selanik'te de kullanmaya devam etmiş gözükmektedir; gerçi bu unvanın geri alındığına dair hiçbir kanıt yoktur. Ancak, Demetrios Kydones'in mektuplarında Manuel'den sürekli basileus olarak bahsetmesi, Manuel'in de bir mektubunda (The Letters of Manuel II Palaeologus, Letter 4) Selanikleri yönetmekten bahsederken özellikle basileuein fiilini kullanması yine de dikkat çekicidir. 1382-1387 arasında Selanik'i Konstantinopolis'ten bağımsız olarak, babasının dış siyasetine tam ters bir politika izleyerek yöneten Manuel'in kendini bir anlamda Selanik imparatoru olarak gördüğü düşünülebilir.

${ }^{10}$ Démétrius Cydonès Correspondance, Ep. 332.

${ }^{11}$ Démétrius Cydonès Correspondance, Ep. 247, satır 24-25.

${ }^{12}$ Démétrius Cydonès Correspondance, Ep. 332, satır 16-26.

${ }^{13}$ Ayrıca bkz Necipoğlu, 'The aristocracy in late Byzantine Thessalonike', ss. 133-151.

${ }^{14}$ The Letters of Manuel II Palaeologus, Letter 4.

${ }^{15}$ Çelik, Manuel II, ss. 103-104.
}

Manuel ve Kydones'in 1386-1387 arasındaki mektupları Selanik'te durumun vahametinin giderek arttı̆̆ını gösterir. Kydones, eski bir öğrencisi olan ve Selanik'e, Manuel'in yanına gelmiş olan Rhadenos'un bile şehri terk etmesini salık verir. Kydones'in mektupları, V. Ioannes'in öfkesinin de - haklı olarak — arttı̆̆ını, hatta Selanik'ten gelen mektupların alıcılara varmalarından önce mühürlerinin açılıp, içeriklerinin imparatorun adamları tarafından okunduğunu belirtir. ${ }^{18}$ Tüm bunları yanı sıra Kydones, Manuel hakkında bir karara varmak üzere imparatorun topladığ 1 kurula önemli bir devlet adamı olmasına rağmen Manuel'e olan yakınlığ nedeniyle alınmaz. Kydones'in mektupları, Manuel'in bu noktada şehri terk etmeyi düşündüğünü de gösterir; kardeşi Theodoros'un yanına, Mora'ya gitmeyi düşünmektedir. Kydones, iki kardeşin birbirine düşeceğini söyleyerek, bu tasarıya karşı çıkar. ${ }^{19}$

Manuel, 1387 yazında Selanik'i terk eder; gitmesinden birkaç gün sonra Selanikliler şehri Osmanlılara teslim ederler. Manuel Midilli Adası'na, I. Francesco Gattilusio'ya sığınır. Bu kararda Gattilusio'yla iyi ilişkiler içinde olan Kydones'in etkili olmuş olması oldukça kuvvetli bir ihtimaldir. Osmanlılarla arasının bozulmasını istemeyen Gattilusio, Manuel'i yine de Mytilene kentine almaz; Manuel ve beraberindekiler bir düzlükte çadır kurmak zorunda kalırlar. ${ }^{20}$ Daha sonra İmroz'a geçen Manuel af dilemek üzere Bursa'ya, I. Murad'ın yanına gider. V. Ioannes ancak bundan sonra Manuel'in Konstantinopolis'e girmesine izin verir. Sonuç olarak, isyankarlığ 1 ve Selanik'i kaybetmesi nedeniyle Manuel'i Limni Adası'na sürer. Manuel burada yaklaşık iki yıl sürgünde kalacak ve ancak yeğeni VII. Ioannes' in isyan hazırlığ

\section{Söylevin İcrası, Edebi Özellikleri ve Temaları ${ }^{21}$}

Selanik başpiskoposu Isidoros Glabas, vaazlarından birinde 13831387 kuşatmasının başlarında Osmanlıların Selanik'e bir ültimatom verdiğini ima eder. ${ }^{22}$ Buna göre Selanikliler ya yüklü miktarda haraç ödemeyi kabul edecek ya da şehir Osmanlılar tarafindan ele geçirilecektir. Hem söylev hem de Manuel'in bu döneme tarihlenen mektupları, pek çok Selaniklinin Osmanlılara teslim olma yanlısı olduğunu yansitır. Manuel söylevini yine kuşatmanın başlarına doğru, Osmanlıların bu ültimatomuna karşın yazıp, toplanan bir mecliste icra etmiştir. Söylevin metnini, dostu ve hocası olan Demetrios Kydones'e de göndermiştir. Manuel ve Kydones'in mektupları, bu söylevin sadece kağıt üzerinde kalmadığına, gerçekten de Selanik'te bir topluluk önünde icra edildiğine dair kanıtlar sunar. Söylevi dinleyen toplulukta kimlerin bulunduğuna dair net bir bilgi yoktur. Demetrios Kydones, Manuel'in yanına Selanik'e yolladığ 1 ve onun maiyetinde görev yapan, eski öğrencisi Rhadenos'un da dinleyiciler arasında bulunduğuna değinir. ${ }^{23}$ Özellikle kriz anlarında, önemli sorunları tartışmak için bir meclis toplanması Geç Bizans döneminde görülen bir uygulamaydı. Örneğin Manuel'in dedesi VI. Ioannes Kantakouzenos da böyle bir meclis toplamıştı. Bu tarz toplantılarda, şehrin ileri gelenleri, ruhban sınıfı ve bazı durumlarda
${ }^{16}$ Çelik, Manuel II, s. 105; Démétrius Cydonès Correspondance, ed. Loenertz, I, Appendix A; Freddy Thiriet, Régestes des délibérations du sénat de Venise concernant la Romanie, 3 vol, Paris Le Haye, Mouton et co, Paris, 1958, I, no. 693, s. 168.

${ }^{17}$ Çelik, Manuel II, ss. 107-108; Dennis, Thessalonica, ss. 130-131.

${ }^{18}$ Démétrius Cydonès Correspondance, Ep. 305, satır 18-22.

${ }^{19}$ Démétrius Cydonès Correspondance, Ep. 342.

${ }^{20}$ The Letters of Manuel II Palaeologus, Letter 38.

21 Makalenin bu bölümü kısmen Çelik, Manuel II, ss. 94-102'ye dayanmaktadır, ancak bu makaledeki tartışmalar detaylandırılmış ve genişletilmiştir.

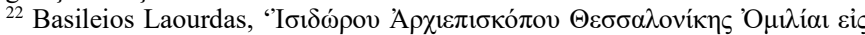

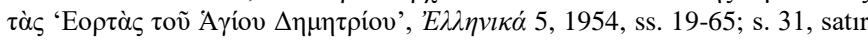
9-11.

${ }^{23}$ The Letters of Manuel II Palaeologus, Letter 8; Démétrius Cydonès Correspondance, Ep. 262. 
da halktan kișiler yer alırdı. ${ }^{24}$ Manuel'in seslendiği toplulukta sadece ruhban sınıfı, archontes ve önemli bürokratların mı bulunduğu, yoksa aralarında halktan kişilerin de bulunduğu belirsizdir. ${ }^{25}$ Manuel, söylevin kendisinde de iki kere eserin bir mecliste (ekklēsia, boulē) icra edilmekte olduğuna değinir. Son olarak Isidoros Glabas'ın bir vaazında Manuel için 'tavsiye veren' (bouleutēs) sıfatını kullanmas da bu söylevin icrasına yapılan bir gönderme olarak düşünülebilir. ${ }^{26}$

Manuel'in söylevinin amacı Selaniklileri Osmanlılara direnmeleri, haraç ödememeleri veya şehri teslim etmemeleri için ikna etmektir. Söylevin kendisi de Selaniklilerin arasında haraç ödemeyi veya şehri teslim etmeyi düşünenler olduğunu siklıkla ima eder. Manuel, Selaniklilerin durumu yeterince ciddiye almamalarından, şehrin savunmasına katkıda bulunmamalarından yakınır. Osmanlıların arzu ettiklerinin Selaniklilerin malları ve mülkleri olmadığını, bizzat onları esir etmek olduğunu savunur. Yani, Manuel'e göre mesele haraç verip vermemekten ziyade, șehrin bağımsızlığı ve vatandaşlarının özgürlüğüdür. Selanikliler haraç vermeyi kabul etseler bile iş orada kalmayacak, șehir eninde sonunda Osmanlıların hakimiyetine girecektir. Manuel'in söylev boyunca sürekli tekrarladığ Selaniklilerin Osmanlılara karşı her türlü zorluğu göğüsleyerek özgürlükleri adına savaşmaları gerektiği, gerekirse bu uğurda ölmeleridir. Manuel'e göre Osmanlıların hakimiyetindeki bir 'esaret' hayatı yaşamaya değer değildir, savaşarak ölmek çok daha onurludur.

Şehrin savunmasına maddi katkıda bulunmanın gerekliliği söylevin diğer bir önemli temasıdır. Şehrin ileri gelenlerinin varlıkların esirgemelerine ve halkın yeni konan vergilerden şikayetçi olmasına, Manuel'in mektuplarında ve Isidoros Glabas'in vaazlarında da değinilir. Söylevde birkaç kere maddi katkıda bulunmanın gerekliği vurgulanır: 'sorunlar biraz para harcayarak çözülebilir'; 'hiçbir kişi malını ve mülkünü esirgememelidir', 'herkes cömert bir şekilde katkıda bulunmalı ve gocunmadan para harcamalıdır.' Bu konu üzerinde özellikle durması, Manuel'in para eksikliğini şehrin savunmasındaki en büyük zorluklardan biri olarak gördüğünü ve halkın en azından bir kısmının maddi katkıda bile bulunmayı reddettiğini gösterir. Söylevde ön planda olan temalardan bir diğeri de esaret (douleia) ve özgürlüktür (eleuthēria). ${ }^{27} \mathrm{Bu}$ sözcükler ve türevleri söylevde yirmi kereden fazla kullanılır. Manuel özgürlük kavramını pek çok Bizans eserindeki yaygın kullanımına uygun düşecek şekilde, siyasi esaretten/bağımlılıktan azade olmak anlamında kullanır. Bu kullanım gayet geleneksel olsa da söylevde üç tür douleia olduğuna dair bir teori ileri sürmesi, Manuel'in bu kavrama yüklediği yenilikçi bir yaklaşımdır. Manuel'e göre, ilk douleia formu, meşru hükümdar ve yöneticilere borçlu olunan itaat ve hizmettir. İkincisi, hükmettikleri insanları ezen tiranlara mecburiyetten boyun eğmektir. Üçüncü ve en kötü olan douleia formu ise amaçları Hristiyanlara zulmetmek olan 'barbarların' esareti altında kalmaktır. Burada ilk ve en iyi olan douleia formu, Manuel'in Selaniklilerden kendisine göstermelerini beklediği itaat ve hizmetle, üçüncü ve en kötü form ise Osmanlılara boyun eğmekle örtüșür. Yani, Manuel bu üç kategoriyi sunarak, Selaniklilerin Osmanlılara teslim

${ }^{24}$ Bkz Constantine N. Tsirpanlis, 'Byzantine parliaments and representative assemblies from 1081 to 1351 ', Byzantion 43, 1973, ss. 432-483 ve Demetrios Kyritses, 'The Imperial council in Byzantium and the tradition of consultative decision-making in Byzantium' Power and Subverison in Byzantium, Papers from the $43^{\text {rd }}$ Spring Symposium of Byzantine Studies, Birmingham, March 2010 (ed. Dimiter Angelov ve Michael Saxby) Ashgate, Farnham, 2013, ss. 57- 67.

${ }^{25}$ Söylevin dilinin oldukça ağır olması, iyi eğitimli olmayan dinleyiciler tarafından anlaşılma olasılı̆̆ını azaltan bir etkendir.

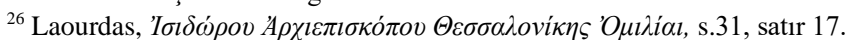

${ }^{27}$ Manuel, douleia kavramına Bir Pers ile Diyalog eserinde de değinir; ancak kelimeyi dinsizliğe esir olmak bağlamında kullanır ve tartışmayı oldukça kısa tutar. Bu eserde, eleutheria kelimesini kullanmaz.

27 Manuel'in dostu ve hocası da Demetrios Kydones de bir söylevinde Bizanslıların özgürlük ve esaret arasında bir seçim yapması gerektiğini

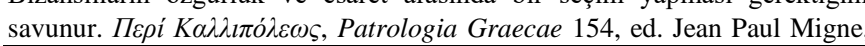

olmayı reddetmesi ve meşru yöneticileri olarak kendisine itaat etmeleri gerektiğini ima eder.

Söylevde özgürlük (eleuthēria) kavramına farklı bir anlamda da değinilir. Manuel, Selaniklilerin sahip olduğu bir takım maddi

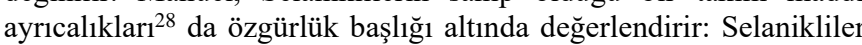
hiçbir zaman diğer Romalıların ve özgür kişilerin imparatorlara vermekle mükellef oldukları vergilere tabii olmamışlardır ve Selanikliler özgürlükleriyle nam salmışlardır. $O$ halde, başka şehirlerin özgürlük kavramına Selanik'ten daha yakın olmaları kabul edilemezdir. Manuel, bu fikirleri kullanarak ve Selanik'in ayrıcalıklarını vurgulayarak, Selaniklilerin kentsel kimliklerine atıfta bulunur. Söylev, Selaniklilerin kentsel kimliklerine ve geçmişlerine başka göndermelerde de bulunur. Manuel, söylevin daha ilk satırlarında Selaniklilere 'Philippos'un topraklarında yaşayanlar' olarak seslenir; ilerleyen bölümlerde de dinleyicilerine Büyük İskender ve Philippos'la aynı anayurdu (patris) paylaştıklarını, onların soyundan (genos) geldiklerini hatırlatır. Büyük İskender'in babası Makedonya Kralı Philippos, İskender'in öncüsü ve Yunan topraklarını fethetmeye başlayan kral olarak Antik Yunan kültüründe önemli bir yere sahipti; üstelik Selanik şehri onun devrinde kurulmuş ve adını onun kızından almıştır. ${ }^{29}$ Manuel, Selanik'in şanlı geçmişini hatırlatarak hem Selaniklileri 'ataları gibi' savaşmaları için yüreklendirmekte hem de Yunanlar ve Persler arasındaki savaşlarla, Selanik ve Osmanlılar arasındaki savaş arasında edebi bir paralellik kurmaktadır. Son olarak, Manuel söylevde Selanik'in koruyucu azizi Demetrios'a da atıfta bulanarak yine Selaniklilerin kentsel kimliklerine hitap etmektedir. ${ }^{30}$ Azizin şehre yardımcı olacağını belirten ve geçmișteki mucizelerini hatırlatan Manuel, azizden ‘bizim' koruyucumuz olarak bahsederek kendisini de bu kültün bir inananı ve şehrin yerlisi olarak tasvir eder.

Osmanlıların tasviri, söylevde önemli bir yer tutar. Osmanlılardan s1klıkla 'barbar' olarak bahseden Manuel, Selaniklileri teslim olma fikrinden vazgeçirmek için onların son derece negatif bir portresini çizer. Söyleve göre Osmanlılar, tüm amaçları Hristiyan şehirleri yakıp yıkmak, halkları esir etmek olan, hiçbir 'medeni' yönü bulunmayan kimselerdir. Haraç talebi bile aslında bir aldatmacadır; Osmanlıların esas arzu ettikleri türlü tuzaklarla bizzat Selaniklileri esir etmektir. Manuel, Osmanlıların Hristiyan olmadıkları hususunu özellikle, sıklıkla vurgular. Selanikliler haraç ödemeyi ya da teslim olmayı kabul ederlerse Osmanlıların onları boyunduruğa vuracaklarını, Hristiyan inançlarını ayaklar altına alacaklarını iddia eder. Osmanlıların 'Mesih'in düşmanı' olduklarını, Hristiyanları ezip, inançlarına hakaret ettiklerini hararetle savunur. Manuel, bu nedenle Osmanlılara karșı savaşmanın Hristiyan Selanikliler için adeta bir dini görev olduğunu vurgular. Selanik şehrinin Hristiyan kimliği de söylevde oldukça baskın bir rol oynar; eserdeki ana temalardan birisi Selaniklilerin sadece siyasi özgürlükleri için savaşmadıkları, Hristiyan inançlarını savunmak zorunda olduklarıdır. Söylevin ilerleyen bölümlerinde, Hristiyan tövbe (metanoia) kavramının detaylıca ele alınması ve Kitab-1 Mukaddes'ten alınan

col. 1009-1036. Geç Bizans eserlerinde özgürlük ve esaret için bkz Dimiter G. Angelov, 'Three kinds of liberty as political ideals in Byzantium, twelfth to fifteenth century', Proceedings of the $22^{\text {nd }}$ International Congress of Byzantine Studies, I: Plenary Sessions, Sofya, 2011, ss. 311-331; ss. 321-326. ${ }^{28} \mathrm{Bu}$ ayricalıkların tam ne oldukları bilinmemektedir; bkz Evelyne Patlegean 'L'immunité des Thessaloniciens', Ev́yvxí . Mélanges Offerts à Hélène Ahrweiler, 2 vol (ed. Michel Balard et al), Paris, 1998, ss. 591-601.

${ }^{29}$ Geç Bizans eserlerinde Büyük İskender ve Philippos imgelerinin kullanımı için bkz Athanasios Karathanassis, 'Philip and Alexander of Macedon in the literature of the Palaiologan era', in Byzantine Macedonia, Identity, Image and History (ed. John Burke ve Roger Scott), Brill, Melbourne, 2000, ss. 111-115. ${ }^{30}$ Aziz Demetrios kültü Selanik şehri ve şehir kimliği için oldukça önemliydi; Selanik'i diğer şehirlerden ayrı kılan bir külttü; bkz Ruth J. Macrides 'Subversion and loyalty in the cult of Saint Demetrios', Byzantinoslavica 51, 1990, ss. $189-197$ 
örnekler eserin dini göndermelerini kuvvetlendirir. Osmanlıların Hristiyan tebaalarına ve haraçgüzar şehirlerine karşı tutumlarıyla çelişen, tarihi olguları yansıtmayan bu söylemlerin amacı Selaniklileri haraç ödeme veya teslim olma fikrinden vazgeçirmektir. ${ }^{31}$ Aksi takdirde Manuel'in Selaniklileri ikna etmek için pek bir kozu ya da mantıklı savunması kalmamaktadır. Sonuçta, Selanikliler Osmanlılara haraç ödeseler ya da şehri onlara teslim etseler aslında çok ciddi zararlara uğramayacaklardır. Haraç ve bazı vergiler vermek zorunda olsalar bile şehrin mevcut ekonomik durumu zaten çok kötüdür ve Manuel savunma için halktan para istemekte, vergiler koymaktadır. Kuşatma ve çatışmalar ş̧ehir halkı için çok büyük sıkıntılara neden olmaktadır. Üstelik Manuel'in iddialarının aksine, şehirdeki Hristiyanlara inanç özgürlüğü tanınacaktır. Tüm bu nedenlerden ötürü Selanik 1387 'de ve 1423 'de iki kere, kendi isteğiyle Osmanlılara teslim olacaktır.

Söylevde Aristoteles etik felsefesinden de izler gözlemlenir. Hristiyan düşünceyle rahatça harmanlanabildiği de için Bizans’ta sıklıkla okunan ve çalışılan Nikomakhos'a Etik eserine Manuel'in oldukça aşina olduğu kendi pek çok eserinden anlaşılmaktadır. Ayrica, 1410lu yıllarda Aristoteles'in bu eserinin yoğun etkilerini gösteren, etik ve siyasi felsefe eseri kaleme alacaktır: Hükümdar Davranışının Temelleri ve Yedi Etik ve Siyasi Söylev. ${ }^{32}$ Hayat boyunca Aristoteles etik felsefesinden kavramları çeşitli eserlerinde kullanan Manuel, bu söylevde bu eğiliminin ilk örneklerini gösterir. Dinleyicilerine esaret, ölüm, yaşamak ve iyi yaşamak' (eu zēn, eṽ $\zeta \tilde{\eta} v)$ olarak dört yol sunan Manuel, bu sonuncu kavramı felsefi bir anlamda kullanır. Aristoteles'e göre $e u z \bar{e} n$, hür iradeyle yapılan seçimler sonucunda rasyonel, erdem açısından mükemmel bir hayat sürmektir. ${ }^{33}$ Manuel de söylevde yaşamak ve 'iyi yaşamak' arasında bir ayrım yapar ve ikincisini hür bir Hristiyan olarak, erdemli bir yaşam sürmekle eş tutar. Söylevde Aristoteles etkisi taşıyan başka kavramlara da siklıkla rastlanır. Aristoteles etik felsefesinde hür

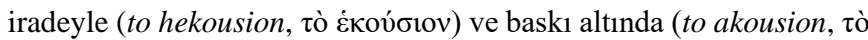

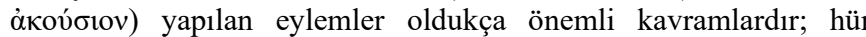
iradeyle yapılan seçim (proairesis, $\pi \rho \circ \alpha i ́ p \varepsilon \sigma ı)$ ) ve onun sonucunda erdeme ulaşılabilmek ancak hür iradeyle gerçekleştirilen bir eylemin sonuncunda mümkün olur. ${ }^{34}$ Tüm bu kavramlar söylev boyunca hem Selaniklilerin hem Osmanlıların davranış biçimlerini irdelemek için siklıkla kullanılır.

Manuel'in söylevi, bir symboulēutikos logos, yani tavsiye/öğüt söylevidir. Kökeni Antik Yunan retoriğine dayanan bu söylevlerin amacı özellikle önemli siyasi, askeri veya sosyal konularda dinleyiciye tavsiye vermek, çözüm yolu önermektir. Hatip, çeşitli sorunları tek tek inceler, çözümlerini irdeler ve bu çözümlere karşı çıkabilecek argümanları çürütür. Söylevin ikna ediciliğinin yüksek olmasına özellikle özen gösterir, bunu çeşitli retorik tekniklerle sağlar: hayali rakiplerin tezlerini çürütmek, dinleyiciye seslenmek, çeşitli örnekler kullanmak, ana motifleri sıklıkla yenilemek gibi. Bizans'ta en çok okunan ve örnek alınan antik hatip olan Demosthenes'in (MÖ 4.yy), özellikle Olynthiaka ve Philippika

\footnotetext{
${ }^{31}$ Erken dönem Osmanlı'da fetihler, kimlik inşası ve Hristiyan tebaaya karşı gösterilen uzlaşmacı yaklaşım için bkz Halil İnalcık, 'Ottoman methods of conquest', Studia Islamica 2, 1954, ss. 108-129; Cemal Kafadar, Between Two Worlds: The Construction of the Ottoman State, University of California Press, Berkeley ve Los Angeles, 1996; Heath W. Lowry, The Nature of the Early Ottoman State, State University of New York Press, Albany, 2003.

${ }^{32} \mathrm{Bu}$ eserler İngilizce literatürde The Foundations of Imperial Conduct ve Seven Ethico-Political Orations olarak bilinirler. Çelik, Manuel II, ss. 319339, bu eserleri incelemektedir.

${ }^{33}$ Aristoteles, Nikomakhos'a Etik, I, iv, 4-5.

${ }^{34}$ Aristoteles, Nikomakhos'a Etik, III, ii, 13.

35 Bizans retoriğinin temellerini olusturan ve el kitapları Bizans'ta sıklıkla çalışılan Tarsuslu Hermogenes Philippika söylevlerini symbouleutikos için model olarak gösterir, Demosthenes'in retorik öge ve stilleri harmanlama tarzının tüm hatiplerin içinde en iyisi olduğunu savunur; $\Pi \varepsilon \rho i$ ' $I \delta \varepsilon \tilde{\omega} v$, Hermogenis Opera, ed. Hugo Rabe, Leipzig, 1913; yeniden basim 1969, ss. 380-385.
}

söylevleri aynı zamanda tavsiye söylevleri için de en önemli modeli oluşturur. ${ }^{35}$ Manuel'in söylevi de hem icra edildiği durum, hem de dil kullanımı ve retorik stil bakımından Demosthenes'ten izler taşımaktadır.

Öncelikle Manuel söylevde bir Antik Yunan şehir devletinin senatosuna seslenen bir hatip konumuna bürünerek Antik Yunan geleneğine öykünür. Üstelik Geç Bizans'ta toplanan şehir meclislerinin halen Antik meclislere benzer yönleri vardır; ${ }^{36}$ Manuel de bu paralelliğin kesinlikle farkındadır. Ayrıca, Manuel'in söylevinin icra edildiği şartlar da bu benzerliği iyice arttırmaktadır. Manuel'in idaresindeki Selanik, imparator unvanlı biri tarafindan yönetilmesine rağmen bir şehir devletine ziyadesiyle benzemektedir; nasıl ki Antik Yunan şehirleri Persler ve Makedonya Kralı Philippos gibi düşmanlar tarafindan tehdit edildiyse, Selanik de Osmanlı tehlikesiyle karşı karşıyadır. Söylevde teslim olma veya direnme seçimini adeta şehir halkının vereceği bir karar gibi sunan Manuel, böylelikle şehir meclisine tavsiye veren hatip rolüne iyice bürünür. Halbuki şehrin hükümdarı olarak esas kararı her halükarda Manuel'in vereceği bellidir, nitekim Selaniklilerin hoşnutsuzluğuna rağmen ilerleyen yıllarda da Osmanlılara direnmeyi sürdürmüş, sonunda şehri terk etmek zorunda kalmıştır. Söylevin amacı bu kararı tartışmak değil, gönülsüz kişileri ikna ederek Manuel'e destek olmalarını sağlamaktır. Söylev, Selanik'in antik geçmişine, Kral Philippos ve Büyük İskender'e de atıfta bulunarak, Osmanlıları Antik Yunanların düşmanlarıyla kıyaslayarak, bu durumu iyice vurgular.

Selaniklilere Tavsiye Söylevi, zaten sofistike bir Attika Yunancasıyla yazan Manuel'in dil ve cümle yapısı bakımından en zor eseri sayılabilir. ${ }^{37}$ Dil özellikleri Demosthenes'le kıyaslandığında Manuel söylevin bir noktasında Birinci Olyntiaka'dan açıç̧a alıntı yapmaktadır, söylevin açılış cümlesi de Birinci Olyntiaka'nın açılış cümlesine biraz da olsa benzemektedir. ${ }^{38} 1390$ senesinde babasının bir hastalıktan iyileşmesi üzerine icra ettiği methiyesinin aksine, Manuel'in tavsiye söylevinde dinleyiciye seslenmeler tıpk1 Demosthenes'de olduğu gibi sıklıkla kullanılır. Erkeklerden oluşan Atinalı bir topluluğa seslenen Demosthenes gibi Manuel'in söylevinde de erkeklik ve erkek olmak kavramları baskın rol oynar. Ayrıca, Manuel'in Osmanlıları tasviri, Demosthenes'in Atina'yı fethetmek isteyen Makedon Krali Philippos'un tasvirini andırmaktadır. Her iki düşman da kibirlidir, askeri bakımdan üstündür, şehirleri sahte vaatlerle kandırıp esir etmektedirler. ${ }^{39}$ Manuel ve Demosthenes'in hatip olarak içinde bulundukları durumlar da oldukça benzerdir. Her ikisi de durumun vahametini anlamayan ve düşmana direnmeye gönülsüz dinleyicileri savaşmaya ikna etmeye çalışmaktadırlar. Yine iki hatip de düşmanların arzuladığının halkın mal ve mülkü olmadığını, bizzat özgürlüklerini ellerinden almak olduğunu vurgular. Sonuç olarak, Manuel'in söylevinde de güçlü bir Demosthenes etkisi gözlemlendiği söylenebilir. Mektup yoluyla söylevi alan Demetrios Kydones eserde adeta 'Demosthenes'in bir yankısını duyduğunu' söylemekte çok da haksız değildir. ${ }^{40}$

${ }^{36}$ Tsirpanlis, 'Parliement', s. 449.

${ }^{37} \mathrm{Bu}$ konuda daha detaylı bir açıklama için bkz Çelik, Manuel II, s. 101.

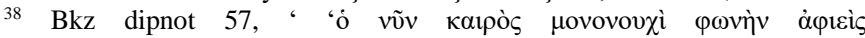

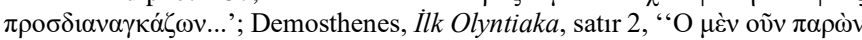

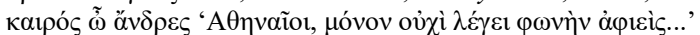

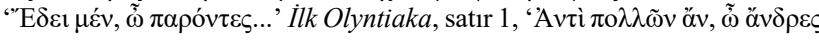

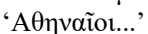

39 Manuel'in Osmanlılardan bahsederken kullandı̆̆

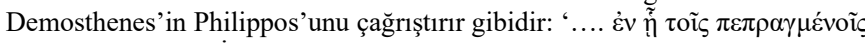

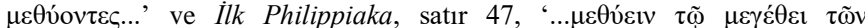
$\pi \varepsilon \pi \rho \alpha \gamma \mu \varepsilon ́ v \omega v . .$. . Ancak, bu rastlantısal bir benzerlik de olabilir; kibiri tasvir ederken sarhoşluk benzetmesi kullanmak Bizans eserlerinde zaten yaygındır.

40 Démétrius Cydonès Correspondance, Ep. 262, satır 24-25. Kydones, Manuel'in söylevindeki Demosthenes etkilerini anlamış olmalıdır, Manuel'in başka eserlerindeki Homeros ve Platon etkilerini de anladı̆̆ mektuplarından belli olur. Ayrıca, Demosthenes model bir hatip olduğu için 
Makalenin kalan kısmında, Selaniklilere Tavsive Söylevi'nin metnin Yunanca orijinalinden yapılmıș Türkçe çevirisi sunulacaktır. Böylece, bildiğimiz kadarıla bu eserin modern bir dile ilk çevirisi yapılmış olacaktır. Türkçe çevirinin akıcı ve anlaşılabilir olması için Manuel'in çok uzun ve karmaşık bir dilbilgisine sahip cümleleri bazı noktalarda bölünmüştür. Dipnotlarda, Manuel'in antik ve dini metinlere yaptığı atıflar da verilmiştir. Söylevin editörü Laourdas'ın tespit ettiği atıf ve alıntılar belirtilmiştir; bunlara makalenin yazarı bazı yeni eklemeler yapmıștır.

\section{Selaniklilere Tavsiye Söylevi, Kuşatıldıkları Zaman}

Ey burada bulunanlar, Philippos'un topraklarında yaşayanlar, ${ }^{41}$ geç ve zorlukla topladığımız bu büyük meclis, ${ }^{42}$ utanç verici bir şekilde barbarlara teslim olmak adına toplanmış olmamalı. Aksine, ey erkekler, ${ }^{43}$ bu meclis, bizim idaremizde ve çevremizde adeta bir çember gibi savaşla kuşatılmış olan o şehirleri ister iyi tavsiyeyle ${ }^{44}$ ister ittifaklar kurarak, veya biraz para harcayarak - ki ihtiyaçlar o kadar artabilir ki hiçbirinizin hiçbir șeyi hiçbir surette sakınmaması gerekir — ${ }^{45}$ kurtarmamız için toplanmış olmalı. Tanrı'nın ve tüm yıldızlardan daha yüce, parlak koruyucumuzun ${ }^{46}$ yardımlarıyla kendisi daima düşmanlarımıza korkunç bir surette görünür, aksine inanmak ise iman etmiş olan bizlere göre ne kutsal ne de dindar bir tutumdur - bu şehirleri eski durumlarına kavuşturursak ve güvenliklerini sağlarsak, bu şehirler bizim için muazzam hendeklerin ve aşılamaz, yıkılamaz surların işlevini görecektir. Bu şehirlerin kurtuluşu ve sizlerin şu anki güvenliği hakkında ancak size uygun düşen ve bunlarr ${ }^{47}$ savunabilme kuvvetinize denk düşen sözleri sarf edersem, iyi tavsiyeler vermiş olur ve imkansız olan hiçbir şeyi önermiş olmazdım. Bu söyleyeceklerimle sizleri ikna eder ve tarafınızdan onay görürdüm. ${ }^{48}$ Üstelik hayran olacağınız sözleri sarf

Bizanslı bir hatibi Demosthenes'e benzetmek büyük bir iltifat olarak görülürdü.

${ }^{41}$ Makedon kralı, Büyük İskender'in babası Philippos. Manuel, İskender'in öncüsü ve Yunan topraklarını fethetmeye başlayan kral olarak Philippos'u da Antik Yunan kültürünün bir parçası yapıyor; onu bir nevi Selaniklilerin atas olarak tasvir ediyor. Selanik de Philippos'un kılarından biri olan Thessalonike'nin kocası tarafindan kurulmuş olup, adını bu prensesten almıstır.

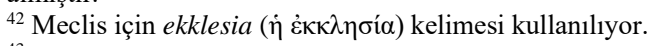

${ }^{43}$ Stil olarak Demosthenes'e öykünen Manuel, özellikle söylevin açılışında sıklıkla Demosthenes'in tarzında dinleyicilere seslenir. Bu söylev, Manuel'in diğer eserleri içinde maskülen tonuyla da dikkat çeker. Demosthenes'te olduğu gibi sıklıkla 'ey erkekler' türünde nidaların yanı sıra, erkek olmak ve erkeksi özellikler de sıklıkla vurgulanır.

44 İyi tavsiyeyle $(\beta$ ov $\lambda \tilde{n} \alpha \gamma \alpha \theta \tilde{n})$ : bu söylevle birlikte kendi de az sonra bizzat tavsiye verecek olan Manuel üstü kapalı şekilde kendini övüyor; Selanikliler onun 'iyi tavsiyesine' vermeli ve şehri her ne pahasına olursa olsun savunmalılardır.

${ }^{45}$ Manuel, söylevde baskın bir tema oluşturacak olan finansal konuları hemen gündeme getirir; özellikle şehrin savunmasına katkıda bulunmayan üst zümreyi hedef almıştır.

46 Selanik şehrinin koruyucu azizi Demetrios'tan bahsediyor. Manuel, Selanik'te çok köklü bir külte sahip olan Aziz Demetrios'a Konstantinopolis'te yaşayan Selanikli arkadaşlarına bu dönemde gönderdiğ mektuplarda da atıfta bulunur. (Nikolaos Kabasilas ve Demetrios Kydones) Selanikli dostlarını, onların koruyucu azizine atıfta bulunarak șehirlerin savunmaya davet eder. Söylevde Demetrios'tan 'bizim kurtarıcımız'

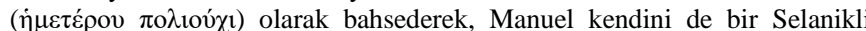
olarak tasvir eder.

${ }^{47}$ Şehirlerin kurtuluşu ve Selaniklilerin şimdiki güvenliği.

${ }^{48}$ Manuel, imkansız olmayan, Selaniklilerin güçlerinin yeteceği önlemlerden bahsedeceğini söylüyor. İma edilmek istenen, Manuel'in az sonra isteyeceğ topyekun savunmanın ve maddi desteğin gayet makul olduğu, isterlerse Selaniklilerin bunu başarabileceğidir. Bu tür tavsiyelerin ikna edici olacağın söyleyen Manuel, az sonra tam da bu tavsiyeleri vereceği için dinleyiciler tarafından onaylanmayı beklediğini ima eder.

49 Manuel burada 'alçakgönüllülük' klişesine (topos) başvuruyor. Bizans söylev yazarları Antik geleneğe uyarak yetersiz bir hatip olduklarını, söylevlerini icra etmenin kendileri için çok zor olduğunu iddia ederlerdi. etmek isteyerek sizin karşınıza hatip olarak çıkmak hiç de kolay bir şey değil. ${ }^{49}$ Zira eğer korktuğunuz şeyler size yakın değilse içinizden çoğunuz pek çok konuya karşı kayıtsızsınız. Örneğin bir hekim, vücudun iltihaplı bölgelerinin sizlamalarının ve hekimlerin hastalıkları teşhis edebilmesini sağlayan buna benzer başka işaretlerin hastalık göstergesi olduğunu söylese ve üstelik ölüm tehlikesi olduğunu eklese bile herkes ölümden nefret etmesine, ondan korkmasına karşın hastalar gereken tedaviye hiç de kolaylıkla uymazlar. Hasta reçeteye uygun şekilde yaşamazsa ise hastalık ölümcül olmasa, sadece tedavisi zor olsa bile şiddetlenir. $\mathrm{O}$ zaman, tıpkı hekimin öngördüğü gibi hastaya önceden dokunmayan ne varsa hepsi tatsız gelir, hepsini yemeden bırakır; hasta olmadan önce tadı çok güzel gelen tüm yiyecekleri ve içecekleri bile kusarken gözlemlenir. ${ }^{50}$ Zorluklar henüz tam doruğa ulaşmadı ve azalmıyorlar, gelecek için bir tehdit olmaktan ziyade şimdi mevcutlar, bize oldukça yakınlar ve onları duymaktan ziyade bizzat görüyoruz. ${ }^{51} \mathrm{O}$ nedenle, elinizden gelen her şeyi yapıp hayatlarınız boyunca her şeyden üstün tuttuğunuz özgürlüğünüzden vazgeçmemeniz için, zorlu bir görev üstelenerek sizin karşınıza çıkıyorum. ${ }^{52}$ Ancak özgürlüğünüzü her şeyden üstün tuttuğunuz için konuşmamın size gereksiz geleceğinden oldukça korkuyorum; tıpkı sizleri Lidya ovasına çağırıyor ya da güzel bir esintiyle denizde yol alan bir gemiyi, kıçında otururken pruvasına bağladığım bir iple, daha hızlı gitsin diye çekiyormuşum gibi. ${ }^{53}$ Şimdi korktuğum hususları sizinle paylaştığıma göre, söze başlıyorum. ${ }^{54} \mathrm{Bu}$ meclis hem şimdiki hem gelecekteki tehlikelerden kurtulmamız için toplandığına göre herkes kendi düşüncelerini söylemeli, kimse tümüyle sessiz kalmamalı. Madem şu anki durum, ${ }^{55}$ insanı sesini yükseltmesi için zorlamakla ${ }^{56}$ ve herkesi bask1 altına almakla kalmıyor, ama kelimelerden ziyade eyleme israrla çağırıyor, ben de birkaç kelimeyle elimden geldiğince gereğini yapacağım. ${ }^{57}$

${ }^{50}$ Yani, ölüm tehlikesi bile olsa hastalar rahatlıklarından vazgeçip, kendilerine zor gelecek tedavilere kolayca razı olmazlar. İmparatorlar için hekim (i $\alpha \tau \rho o ́ \varsigma$ ) benzetmesi kullanmak Bizans eserlerinde yaygın bir temadır; kökeni İsa Mesih'in ruhların hekimi olması anlayışına dayanır. Manuel, söylevde bu geleneksel doktor benzetmesine başvuruyor. Yine de Manuel'in buradaki detaylı hasta ve hastalık tasviri alışılagelmiş kalıpların biraz dışına çıkmaktadır. Vermek istediği mesaj ise, Osmanlı kuşatmasının son derece tehlikeli bir 'hastalık' olduğu, Osmanlılara teslim olurlarsa Selaniklilerin ölmeseler bile çok ciddi sıkıntı çekecekleridir. Selanikliler, kulağa her ne kadar zor gelirse gelsin, 'hekimleri' Manuel'in reçetesine uymalı ve şehirlerini ölüm pahasına savunmalıdırlar.

${ }^{51}$ Tehlikenin tam kapıda olduğunu ima ediyor; Selanikliler Osmanlıların yol açtığ felaketleri başkalarından duyarak öğrenmiyor, bizzat şahit oluyorlar.

52 Zorlu görev olarak çevrilen agōn (ó $\dot{\alpha} \gamma \tilde{\omega} v)$ terimi, esasen azizlerin çilecilikleri ve mitolojik kahramanların görevleri için kullanılırdı. Söylev vermeyi bir agōn olarak tasvir etmek Bizans eserlerinde çok yaygın bir benzetmedir.

Özgürlük ( $\dot{\eta} \dot{\varepsilon} \lambda \varepsilon v \theta \varepsilon \rho i ́ \alpha)$, söylevdeki en baskın temadır. Bu özgürlük temasina, Manuel ve Demetrios Kydones'in 1382-1387 arasındaki mektuplaşmalarında sıklıkla rastlanır; ikisinin de değindiği bu tema sadece bu döneme özgüdür.

53 'Lidya ovasına çağırmak': Bizans eserlerinde yaygın kullanılan bir deyim, boș veya gereksiz bir iș yapmak anlamına gelir. Kıçtan pruvaya bağlı bir iple, oturduğu yerden gemiyi çekmek benzetmesi Manuel'e özgüdür; ima edilen yine gereksiz, sonuca erişemeyecek, anlamsız bir iş yapılmasıdır.

${ }^{54}$ Söylevin girizgâh kısmından ana konuya geçmektedir.

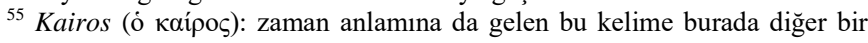
anlamı olan 'durum' olarak kullanılıyor.

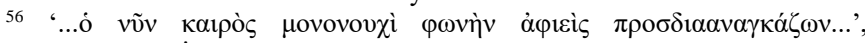
Demosthenes, Illk Olynthiaka, satır 1-2 (Laourdas, s. 296). Demosthenes, Bizans eserlerinde en sık alıntı yapılan ve en çok model alınan antik hatipti. Bu söylevde, Manuel bu alıntının yanı sıra Demosthenes'in stiline de öykünür. 57 Mevcut durumun amel, iș gerektirdiğini, hemen harekete geçmek

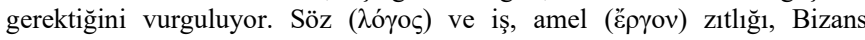
eserlerinde sık kullanılan bir motiftir. Burada söz yerine iş gerekmesi fikrinde biraz da ironi yapılmaktadır; çünkü Manuel de tam o anda konuşmakta, bir söylev $(\lambda o ́ \gamma o \varsigma)$ vermektedir.

'elimden geldiğince' ve 'birkaç kelimeyle': yine alçak gönüllük klișesine başvuruluyor; ayrıca söylevlerin çok uzun olmaması, az kelimeyle çok fikir anlatabilmek Bizans retoriğinde çok makbul sayılan bir özellikti. 
Barbarların size şimdi ${ }^{58}$ geçirmek istedikleri esaret boyunduruğunun tüm insanlar için en ağır yük olduğunu ve ne kadar utanç verici olduğunu söylevimin kanıtlamasına gerek yok. Tanrı sizleri herkesten daha çok onurlandırdığı için, siz özgürlüğ̈̈nüzden mahrum kalırsanız yaşamlarınızın katlanılamaz olduğunu düşünürsünüz. Farklı kulluk biçimleri vardır ve bunlar birbirlerinden oldukça farklıdırlar. ${ }^{59}$ Bunlardan biri iktidar sahiplerinin ataların düzenini korumakla mükellef olduğu bir düzende meşru iktidar sahiplerine kulluktur; bir diğeri ise kendileri için hükmetmenin tebaalarını her gün ezmek anlamına gelen tiranlara kulluktur. ${ }^{60}$ Barbarların kölesi konuma düşmek ise kelimelerin tarif edemeyeceği kadar kötü bir duruma düşmek demektir; barbarların tek bir yasası ve daima sürdürülecek tek bir işi vardır: İsa'nın ümmetine kötü söz söylemek ve eziyet etmek. ${ }^{61}$ Ama bu kulluk biçimleri bile farklı halklar tarafından farklı şekillerde yaşanır. Özgürlügü gögün yüksekliği gibi ziyadesiyle seçkin ve tanınmış olan sizler ise — ki başka özgür halklar da vardır — şimdi barbarların size yüklemeyi layık gördüğü şeylerden hiçbirini hiçbir zaman iktidar sahiplerine borçlu olmadınız. Hatta Romalıların ve özgür insanların imparatorlara vermekle mükellef oldukları vergilere bile asla tabii olmadınız. ${ }^{62}$ Peki neye tabii idiniz? Tüm bunlar yerine inayete ve bu inayetten daha bile büyük, evlatların babalarına borçlu olduğu bir sevgiye sahiptiniz. Tüm bunlar yerine amellerinizle gösterdiniz ki pek çok hediyeyle onurlandırılmış olan sizler, ziyadesiyle hak ettiğiniz bu ihsanları durumunuz iyiyken artırıyor ve bollaştırıyordunuz. ${ }^{63}$

Şimdi düşmanların ne zaman üstün hale geldiğini ve şehirlerin yağmalanmalarını etraflıca ele alalım; o şehirler ki bir zamanlar bizimdi, şimdi ise - ah, Mesih! - onların herkesçe bilinen kötï durumlarını ve yakıcı çilelerini, umutsuzluklarını tek tek anlatmak oldukça gereksiz olacak. ${ }^{64}$ Başlarına gelenlerin yeterince açıkça anlattığı gibi, onlar civardaki şehirlerin düşüşlerine tanıklık etmelerine rağmen kendilerini çevreleyen küçük şehirlerin durumlarına kayıtsız kaldılar, bırakın diğer şehirlerin güvenliğini, kendi güvenliklerini bile gereğince korumadilar. ${ }^{65}$ Mevcut durum böyle olduğuna göre - ki önceki günler ve olup bitenler buna şahitlik ediyor- boş durmayalım, kendi kurtuluşumuzu hafife almayalım. Hatırlamalıyız ki bizler Romalıyı, Philippos ve İskender'in vatan bizim de vatanımız, ${ }^{66}$ bizler çok uzun bir geçmişten beri bu çifte

58 Tehlikenin ne kadar yakın olduğunu, bir an önce harekete geçilmesini

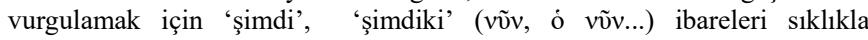
kullaniliyor.

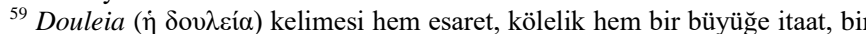
hükümdara kulluk, hizmet anlamına gelir. Burada kulluk olarak çevrilmesi daha doğru olan douleia terimini Manuel bir önceki cümlesinde Osmanl hakimiyetine girmekten bahsederken esaret, kölelik anlamında kullanıor:

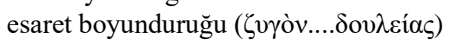

${ }^{60}$ Eunomōs (Ev่vó $\left.\mu \omega \varsigma\right)$ yasal, meşru olarak. Bir hükümdarın yönetiminin yasal, meşru olması Bizans ideolojisinde önemli bir siyasi kavramdı. Böyle bir

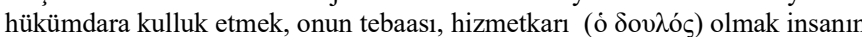
bir göreviydi. Burada Manuel'in özellikle kast ettiği yönetim, Bizans imparatorluk sistemidir. Kendisini Selanik'in meşru yöneticisi ve imparatoru gördüğü için, Selaniklilerin kendisine itaat ve kulluk borçlu olduğunu da ima ediyor.

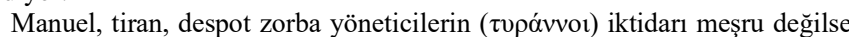
de halkın korku ve çaresizlikten biat edeceğini söylemek istiyor.

${ }_{61}$ Manuel söylevin bu noktasından itibaren, Selaniklileri Osmanlılara direnmeye davet ederken, Hristiyanlığa değinmeye başlıyor.

62 Manuel burada, Selanik şehrinin sahip olduğu bir takım finansal ayrıcalıklara değiniyor. Selaniklilerin diğer șehirlerden daha imtiyazlı, daha özel bir özgürlüğe sahip olduğunu vurgulayarak onları Osmanlılara teslim olma ve haraç verme fikrinden caydırmaya çalışıyor.

${ }^{63}$ Yani, siyasi ve askeri bir tehdit yokken; şehir barış ve sükûnet içindeyken.

64 Özellikle Balkanlarda nispetle yakın zamanda Osmanlılara kaybedilen şehirlerden bahsediyor olmalı; 1383'te Osmanlılar Makedonya'nın büyük bir kısmını ele geçirmişlerdi. 1360-1370 yıllarında da Trakya'da da önemli şehirler kaybedilmişti; örneğin Dimetoka, Edirne ve Filibe.

${ }^{65}$ Manuel, bu gidişatla Selanik'in de aynı sona uğrayacağını ima ediyor. soyun mirasçılarıyız. ${ }^{67}$ Hatırlamalıyız ki onlar düşmanlarına karşı savaşa gittiğinde herkesi hakimiyetlerine alırlardı ve hiç kimse onlara karşı duramazd1, tıpk1 tozun güçlü bir rüzgara, balmumun ateşin alevlerine karşı duramadığı gibi. Üstelik onların düşmanları, Persler, İskitler, Paionialılar, Keltler, dişarı adaların sakinleri68 ve daha nice sayısız ırk, tıpkı bir şairin diyeceği gibi hedefi şaşmayan yaylarla donanmışlard1 ${ }^{69}$ mızrak kullanmakta, at binmekte ve savaş alanında manevra yapmakta ustalard1. Bunlar gibi bir orduyu muzaffer kılan ne kadar askeri bilgi varsa hepsine tümüyle vakıf olduklarını gösterirlerdi; şimdi bizim karşımıza dikilenler bu geçmiş düşmanlara kıyasla bir hiçler. Yaşamlarını elleriyle çalışarak sağlıyorlar ve onlara köle olmak karşılığında kendilerinden hayatta kalma şansının satın alınmasını pek büyük bir başarı sanıyorlar. ${ }^{70}$ Ey yukarıda bahsi geçen kişilerin torunları, tüm bunları aklımızda bulundurarak gerektiği gibi harekete geçelim, şehirleri düşman elinden kurtarabilecek hiçbir şeyi göz ardı etmeyelim ve belki dışarıdan bir yerden yardım geleceği hülyasına bel bağlamayalım. Barbar oldukları için düşmanlarımız sefahat düşkünü ve şana pek önem vermiyorlar ancak uzun süredir yaptıkları gibi büyük miktarda haraç topluyorlar. ${ }^{71}$ Buna rağmen sırf sizi boyunduruğa vurabilmek için rahat dinlenceden ve o çok sevdikleri safahattan uzaklaşıp, bu uğurda ellerinden gelen her şeyi yapıyorlar. Eğer onlar için durum böyleyse, sizlere yakışan barbarların bize karşı giriştiği o haksız mücadelede çabalarınızla onları geride bırakmaktır. Üstelik, İstros'tan size kadar uzanan tüm liman şehirlerinin, Euboia şehirlerinin ve hatta barbarlarının gücünün en kuvvetli olduğu doğudaki şehirlerin, özgürlük hakkında sizden daha fazla söyleyecek şeyi olması katlanılamaz bir durumdur. ${ }^{72} \mathrm{Bu}$ noktada, gerçeği gözler önünce serecekse paradoksal bir akıl yürütme kullanmanın hiç de mantıksız olmadığını düşünüyorum. Farz edin ki bu şehirlerde hem onların vatandaşlarından hem de Selaniklilerden orada ikamet edenlerden vefat edenler oluyor. Sizin yurttaşlarınızın bedenlerini yurda getirmeleri mümkün olmadığı için onları kendi vatandaşlarıyla aynı mezara layık görmeleri gerekirken canavarca bir iş yapıyorlar, sizin vatandaşlarınızın bedenlerini alacak bir başka toprak parçası bulunmazsa onları derin sulara atıyorlar; bu yaptıkları kendilerinin yabancı topraklarda daima güçlü görünen insanların dengi olmadığı gösterecek olsa bile. ${ }^{73}$ Eğer, düşmanlar — onlara düşman diyoruz çünkü Mesih efendimize gerçekten düşmanlar ve bu yüzden bizim de düşmanımızlar - sizin tarlalarınıza ve tüm

${ }^{66}$ Patris (ं் $\left.\pi \alpha \tau \rho i ́ \varsigma\right)$ vatan, anayurt. Selanik'i Makedonya Kralı Philippos ve oğlu Büyük İskender ile ilişkilendirerek, Selaniklilerin 'vatanseverliklerine' ve şehir gururlarına hitap etmeye çalışıyor.

${ }^{67}$ Hem Philippos ve İskender soyunun hem Roma soyunun mirasçılarıdır. Bu cümle, Manuel'in eserlerinde oldukça arkaik bir kullanım olan tesniye

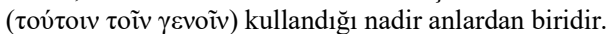

68 Büyük İskender'in ve Romalıların düşmanları; Persler: Ahamenişler, Paionialılar: günümüz Macaristanında yaşayan halklar, Keltler: genel anlamıyla Avrupalı kavimler, dıșarı ada sakinleri: Britanya'nın eski halkları. Bizans eserlerinde bu arkaik isimler sıklıkla, hatta çağdaş halklar için bile kullanilırdı.

${ }^{69}$ Aiskhlyos, Zincire vurulmuș Prometheus, satır 711; ancak Manuel'in eseri mi okumuş olduğu yoksa sadece alıntı yaptığı cümleyi mi bildiği belirsizdir.

${ }^{70}$ Bizans düşünürlerince elleriyle çalıșmak, fiziksel is yapmak hor görülürdü; Manuel Osmanlıların hayat tarzını 'aşağı' olarak tasvir etmeye çalışıyor.

İslam hukukuna göre Osmanlılar teslim olan şehirleri yağmalamaz ve halkını esir etmez, can güvenliğini sağlardı. Bu nedenle, Selanikliler dahil olmak üzere bazı Bizanslılar Osmanlılara teslim olmayı tercih ediyorlardı. Manuel bu tutumu kınadığını, Selaniklilerin hayatta kalmak uğruna Osmanlı hakimiyetini kabul etmemesi gerektiğini ima ediyor.

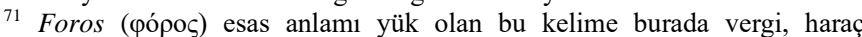
anlamında kullanılıyor. Osmanlılar haraçgüzar konumuna getirdikleri bölgelerden haraç alıp, direkt topraklarına kattıkları yerlerdeki gayrimüslimlerden de cizye vergisi alırdı.

72 Geçmişi ve sahip olduğu imtiyazlar nedeniyle, Selanik'in başka şehirlerden 'daha az özgür' olması kabul edilemezdir; Manuel böyle bir durumun Selaniklilerin onuruna dokunması gerektiğini ima ediyor.

${ }^{73}$ Söylevin ilerleyen kısımlarına Selaniklilere gerekirse savaşarak ölmelerini söyleyecek olan Manuel, bu fikri çağrıștıran bir örnek veriyor. Ancak, Yunanca pasajın tam olarak ne dediğini çözmek oldukça zordur; anlamı açık değildir. 
topraklarınıza sizin için kabul edilemez olan bir haraç, diğer şehirlerin ödedikleri gibi bir haraç koymak istiyorsa en başında bu konu hakkında meclis toplamış olmak utanç verici olmalı. ${ }^{74}$ Eğer bu durum utanç verici ise, daha sağlam bir kuvvete başvurmak mümkünken barbarlara haraç vermek bundan çok daha utanç vericidir. Zira şimdi sizin sahip olduklarınızı değil bizzat sizi ele geçirmek ve arzuladıkları gibi kullanmak istiyorlar; her ne kadar söyledikleri sözlerle tam bunu kastediyor gibi durmasalar da aslında aldatmacaya başvuruyorlar, eski tanıdık yalanlarını söylüyorlar. ${ }^{75}$ Diğer şehirleri başka sözlerle kandırıp yağmalamış değiller, sizi kandırmak için sarf ettikleri aynı sözlerle bunu başardılar. Akıl sahibi olmayan hayvanlar ve kuşlar bile tuzakları ve ağları görüp tanırlarsa bunlarla kolayca avlanamazlar. ${ }^{76}$ O halde açıkça aptal laflara kanmayıp da, diğer şehirleri yağmalayıp esir etmelerini sağlayan ve şimdi de aynı şekilde bizi esir etmeye çalışırken sarf ettikleri aynı sözleri haykıran bir yazıya kanmak gerçekten gülünç olmaz mı? ${ }^{77} \mathrm{Ah}$, barbarların bize karşı olan kibirleri ve mantıksızlıkları! Çok daha zayıf olanlardan almak isteyip de alamadıklarını sizden elde etmeyi bekliyorlar. Ah, bazı insanların soysuzlukları ve akılsızlıkları! Zira tüm şehirlerden daha zayıf göründüklerini idrak etmeleri gerekirken, aksine bu meclisin toplanmaması gerektiğini düşünüyorlar. ${ }^{78}$

Ey soylu adam, ${ }^{79}$ tam da bu sebepten ötürü bu meseleyi düşünmek bile gereksizdir! Zira biz köle olmayız — bu fikrin kulağa bile garip geldiğini sizler de iyi biliyorsunuz - ama bize yakışanı yaparız. Tanrı yardımcımız olursa, biz kendimiz efendiler olup, silah kuşanıp, şan uğruna ölmeyi seçtiğimiz sürece düşmanlar bizim efendilerimiz olmaz, asla olamaz! Nihayetinde ölmek kaçmak değildir. Size onurlu gelmeyen bir şeyi muhafaza etmek ve sahip olduklarınızdan vazgeçmek ise, ey Mesih, en düşünülemez durumdur; çünkü köleler kendilerine bahședilmeyen hiçbir şeye sahip olamazlar, kaybedilen şeyler ise tekrar kazanılamaz! ${ }^{80} \mathrm{Bu}$ meseleler hakkında yeterince konuştuğuma göre, ey erkekler, esas konuyu tekrar ele alacağım. Eminim ki hepimiz doğamızın ortak borcunu, yani ölümü, dinsiz barbarlara kendi hür rızamızla esir olmaya tercih ederiz. Onlar hem sözleri hem eylemleriyle ellerinden geldiğince Efendimize hakaret ederler, üstelik kendilerine esir olanları da kendi dinsizliklerine zorlamaktan geri durmazlar; ${ }^{81}$ kendilerinin efendi olduklarını sansalar da aslında köle kadar zavallıdırlar. Zira onlara savaş esiri düşmüş veya başka bir şekilde onların boyunduruğuna girmiş insanların kudretli efendileri olsalar bile, aslında onlar kötü şeytanların gönüllü kötü köleleridirler. ${ }^{82} \mathrm{Bu}$ zorlayıcı kuvvetleri sıklıkla pek çok insanı alt etti, ancak esir ettikleri içinde daha soylu

74 Manuel, dinleyicilerin dini duygularına hitap ederek ve Osmanlılar Hristiyanlığın düşmanı olarak tasvir ederek Selaniklileri direnmeye dave ediyor. Bu durumda Osmanlılara haraç ödemeyi veya teslim olmayı düşünmek bile utanç vericidir; Selaniklilerin direnmeye ikna etmek için bir meclis toplamak zorunda kalmak bile başlı başına bir utançtır.

${ }^{75}$ Osmanlıların esas arzuladığı şeyin haraç olmadığını, bizzat Selaniklileri esir etmek olduğunu söylüyor. Teslim olurlarsa sadece haraç ödemek zorunda kalacakları vaadinin yalan olduğunu iddia ediyor.

${ }^{76}$ Kendi de avlanmaya düşkün olan Manuel, eserlerinde sıklıkla av hakkında benzetmeler kullanır.

77 Yazı ( $\gamma \rho \alpha \varphi \tilde{n})$ : Isidoros Glabas'ın de değindiği gibi, Osmanlılar Selaniklilerden șehri teslim etmeleri ya da büyük miktarda haraç ödemeler talebinde bulunmuşlardır; Manuel'in yazıdan kasti Selanik'e gönderilmiş yazılı bir talep olabilir.

${ }_{78} \mathrm{Bu}$ ve önceki cümle, Osmanlılara haraç ödemeyi ya da teslim olmayı düşünen Selaniklilere hitap etmektedir. Bazılarının bu meclise bile karşı çıkacak kadar Osmanlılara boyun eğme taraftarı olduğunu belirtiyor.

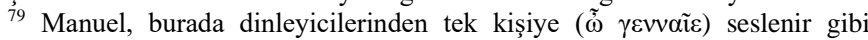
yapıyor, bu yaygın kullanılan bir retorik tekniğidir.

${ }^{80}$ Onursuzca yaşayacaklarına ve sahip olduğu özgürlükleri kaybedeceklerine ölmeyi tercih etmelidirler. Teslim olursa, Osmanlıların inayetine bağlı olarak yaşayacak, sahip oldukları her şey onların bir lütfu olacaktır. Özgürlüklerini ise bir kere kaybederlerse, bir daha kazanamazlar.

81 Efendimiz: İsa Mesih. Osmanlıların Hristiyanları din değiştirmeye zorladığını iddia ediyor; halbuki Osmanlıların böyle bir politikası yoktur.

${ }^{82}$ Manuel, Osmanlıların Hristiyan olmadıkları için tüm başarılarına rağmen zavallı ve kötü olduklarını söylüyor. düşüncelere sahip olan kişileri kendi düşüncelerine döndüremedikleri zaman hiç de öyle kudretli gözükmeyeceklerdir. Ama, ölümü göze alamayacak korkaklar, onların hukuksuz ve dinsizlikle dolu eylemlerine tanıklık etmek, dine küfretmelerini dinlemek ve korkuyla sinip, sessiz kalmak zorundadırlar. Çünkü sessiz kalarak onların küfür dolu sözlerine ve eylemlerine ortak olmaktan ve böylece onların dinsizliklerine ortak olmaktan ziyade İsa Mesih adına ölüme susamayı göze almak ve en büyük amellerden gelen şanı azımsamamak şarttır. ${ }^{83}$

O nedenle, az önce de söylediğim gibi, bence ölüm böyle bir esaretten daha iyidir. Sizlerin de bu görüşe katıldığınızı, geçmişteki tüm erkeklerin bu görüşe katılmış olduklarını ve şimdi yaşayan tüm erkeklerin de katıldıklarını biliyorum - tabii eğer bir erkek, çocuk aklına ve kadınsı, köle bir ruha sahip olup da köleliğin hür iradeyle sürdürülen bir hayattan farklı olmadığını düşünmüyorsa ${ }^{84}$ Ben böyle bir erkeğin ırkına sürülmüș bir leke ve erkekliğin yüzkarası olduğunu, meclise girerse tek bir kişinin bile onu dinlemeyeceğini düşünürüm ve bu düşüncemden gayet eminim. ${ }^{85}$ Zira kim böyle bir adama kulak verecek kadar delirmiş olabilir? Ey Romalı erkekler, layığı kadınlarla güçsüz bir şekilde oturmak olan böyle bir adamı bizim meclise almamız bile çok büyük bir utançtır! Böyle bir adam ancak 1slah edilmesi gereken biridir. Eğer 1 slah edilemezse bırakın bizler için acınası biri olarak kalsın; biz söylevimizin sonuna ilerleyelim. Ölümün esaretten daha iyi olduğunda karar kıldık ancak yaşamak da ölümden iyidir, iyi yaşamak da ondan iyidir. ${ }^{86}$ Esaret, ölüm, yaşamak ve iyi yaşamak olarak dört seçeneğimiz varken, sizler esaret lafını bile bir kenara attığınıza ve onun yerine ölümü kucakladığınıza göre amacıma ulaştım. Mümkünse şunu da söylemek isterim: ölümü kucaklamışken bile ölümü beklemek yerine istediğiniz şekilde yaşamak için çalışabilirsiniz; bunu insan zihnini eğiten O'nun sayesinde, Paulos'un dediği gibi 'bir şeyi istemeyi ve gerçekleştirmeyi bizlerin ruhuna işleyen'87 O'nun sayesinde yapabilirsiniz. Bunu söylemesem bile zaten esaret boyunduruğu yerine ölümü onurlandırmayı seçtiğiniz için çok da bir şey fark etmezdi. ${ }^{88}$ Yine de bu sözleri söyleyelim: nasıl ki esir olmamak adına ölümle gönüllü bir şekilde dost olduysak, aynı şekilde ölmemek için de firtına gibi esen pek çok zorluğa katlanmamız, silahlarımıza sarılmamız, aldığımız yaraları umursamamız ve herkesin gerekli tüm işlere hem kendi başına hem toplu olarak sıkıca sarılması gerekir. ${ }^{89}$ Çünkü, eskilerden bir bilgenin dediği gibi, doğa insana taşıyamayacağı hiçbir yükü yüklemez; onur ve yaşam uğruna zorluklarla boğuşmak gerektiği zaman diye bir de ekleme yapayım. ${ }^{90}$

${ }^{83} \mathrm{Bu}$ şan, Hristiyanlık uğruna ölmektir. Manuel, Osmanlılara teslim olanları zayıf, korkak ve dinlerine yeterince bağlı olmayan, onu savunamayacak kişiler olarak betimliyor.

${ }^{84} \mathrm{Bu}$ noktada Manuel söyleve iyice erkeksi bir hava veriyor; geçmişte yaşamış ve șu an yaşayan tüm erkeklerin esarettense ölümü tercih etmeleri gerektiğini, aksi takdirde 'erkek' sayılamayacaklarını ima ediyor. Çocuk aklına ve kadınsı ruha sahip olmak gibi özellikleri aşağılayıcı bir şekilde kullanıyor. Demek istediği, Osmanlılara teslim olmayı düşünen Selanikli erkeklerin de böyle olduğudur.

${ }^{85}$ Teslim olma düşüncesinde olan Selaniklilere mecliste kimsenin kulak vermemesi gerektiği ima ediyor.

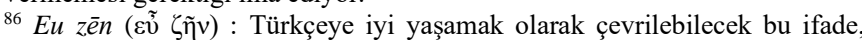
erdemli yaşamak, mükemmel bir erdem ve memnuniyet durumda bulanmak anlamını içeren felsefi bir kavramdır. Aristoteles'in etik felsefesinden oldukça etkilenmiş olan Manuel, bu kavramı eserlerinde sıklıkla kullanır.

${ }^{87}$ Philippos Belgeleri 1, 13 (Laourdas, s.300)

${ }^{88}$ Manuel, sanki dinleyicileri şimdiden kararlarını vermiş, savaşmayı tercih etmiş gibi konuşarak söylevinin ikna gücünü arttırmaya çalışıyor; sanki verilebilecek tek mantıklı veya onurlu karar savaşmakmış gibi davranıyor. $\mathrm{Bu}$, Bizans söylevlerinde kullanılan bir retorik tekniktir.

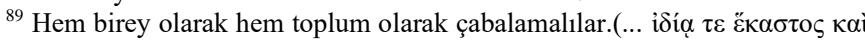
кoเvị.)

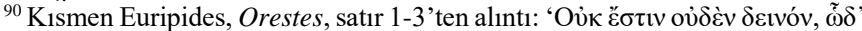

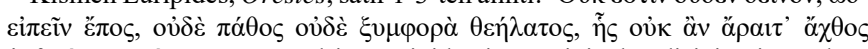

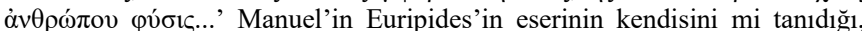
yoksa bu cümleyi anonim bir deyim olarak mı bildiği belli değildir. Manuel bu deyimi başka eserlerinde de kullanır. 
Tanrı'nın da yardımıyla, para harcayarak düşmanlarımızı — ki bize karşı savaş açmaya çok istekliler - pişman edecek eylemler gerçekleştirmeniz mümkün. $\mathrm{O}$ halde, onlarla anlaşma yapıp, tehlike ve zorluklardan kurtuluş yolunu onurlu ve keyifli olan ne varsa onların karşıllğında satın almanızın nasıl sizler için kazançlı olabileceğini düşünürsünüz? ${ }^{91}$ Eğer bu sahip olduklarımızı koruyacak, utanç verici ve zararlı şeylerin sebebini ortadan kaldıracaksak, aklı başında olan herkes içinde bulunduğumuz durumu düzeltmek için para harcamayı bir kazanç sayar. ${ }^{92}$ Üstelik ümitleri yitirmemek gerekir, aksine hatibin de dediği gibi erdemli erkekler ümidi tıpkı bir zırh gibi kuşanmalı ve bir kalkan gibi kullanmalıdırlar. Eğer bu şehri aşağılamaya çalışan düşmanlarımızı bazen anında, bazen bir süre sonra fazlasıyla cezalandıran büyük Demetrios ${ }^{93}$ bizlere kumanda ediyorsa, kibirli ve hayalci düşmanlar — bazen savaş gemileriyle, bazen korsan gemileriyle ve bazen de başarılarıyla zafer sarhoșu oldukları karada - az bir uğraşla sizleri büyük bir utanca boğmaya istiyorsa, daha düşünmeye ne gerek var? Düşmanlar her şeyi yapabileceklerini ve sizlerle ilgili emellerine sizlerin kendi faydanıza olan planları yapabilmenizden bile daha kolay ulaşabileceklerini sanıyorlarsa, ancak biz onlara karşı cesaretli ve bilgece harekete etmek istiyorsak, ey erkekler, daha düşünmeye ne gerek var? "Ama düşmanlar para, müttefik, toprak ve ordu olarak bizden çok daha iyi konumdalar, barış istemek için onlara elçi göndermeliyiz!"94 Katıliyorum ey dostum, bunu yapmaya beni iten çok neden var, ama hepsini bir kenara atmak gayet kolay; katı bir adam zannedilmekten korkmama rağmen, her bir nedeni iyice inceledim ve zorluklara katlanmak gerektiğine karar verdim. Sana fikrimi söyleyeyim, eğer anlaşma yapılırsa - yani barbarın "anlaşma" dediği o şey gerçekleşirse - dikkat edin ki sizi aldatmasın ve anlaşma konuşmalarıyla esaretle sürüklemesin. Zira deneyimlerimizin de gösterdiği gibi, bu adamın aldatmacasının bir balıkçının küçük yemlerle büyük avları yakalayabilmesinden hiçbir fark1 yoktur. ${ }^{95}$ Hristiyanların topraklarını uzunca süredir —nasıl ki dev bir dalga kıyıdaki küçük bir kayayı su altında bırakırsa — sel gibi basmasının ve işgal etmesinin sebebi, ordusunun büyüklügü, inanılmaz bir güce ve cesarete sahip olması veya herkesten daha zeki olması değil, aynı șekilde herkesten zengin olması ya da hiç değilse

${ }^{91}$ Osmanlılarla barış için ödenecek olan haraç için para ayırmak yerine, aynı parayı şehrin savunmasına harcarlarsa başarılı olabileceklerini öneriyor.

92 Savunmaya para harcayarak, özgürlüklerini ve onurlarını koruyabilirler.

${ }^{93}$ Yine Selanik'in koruyucusu Aziz Demetrios'a değiniyor. Düşmanlara karș bazen derhal hareket geçmese bile, eninde sonunda onları yeneceğini, şehre yardım edeceğini ima ediyor. Manuel'in Aziz Demetrios hakkındaki bu sözlerinin bir benzer bir ifadesi de Selanik kuşatması sırasında Nikolaos Kabasilas'a yazdığ Palaeologus, Letter 19.

${ }^{94}$ Manuel, teslim olmak gerektiğini düşünen bir kişinin ağzından konuşur gibi yapıyor; karşıt düşünceleri açıklarken ve çürütürken yaygın olarak kullanılan bir retorik tekniğidir.

95 Bu iki cümlede Osmanlılardan 'barbar' (ó ßá $\beta \beta \alpha \rho \varsigma$ ) ve 'adam' (ó

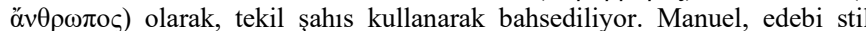
unsuru olarak, sembolik olarak 'bir' barbardan bahsederek aslında yine çoğul olarak Osmanlıları kastediyor olabilir. Tekil şahsa geçmesinin bir diğer açıklaması bu iki cümlede bilhassa Sultan I. Murad'ı kastetmesi olabilir.

${ }^{96} \mathrm{Bu}$ garip cümlede Selaniklilerin Osmanlıları rakip olarak gözlerinde çok da büyütmemeleri gerektiğini, aslında tüm başarılarını büyülere ve tılsımlara borçlu olduklarını iddia ediyor. Düşmanın büyü sayesinde başarılı olması gibi bir iddiayla Osmanlıları Selaniklilerin gözünde iyi itibarsızlaștırmaya çalışıyor. İma ettiği, ‘inançlı’ Hristiyanların ve Selaniklilerin eninde sonunda galip geleceğidir.

${ }_{97}$ Pronoia ( $\eta$ $\left.\pi \rho o v i ́ \alpha\right)$; tanrısal tasarruf. Manuel'in burada barıștan kasti, Osmanlıların haraç talep etmeden kuşatmayı kaldırması ve kalıcı bir barış ortamı sağlanması olabilir, zira haraç ödeyerek barıș elde etmeye karșı

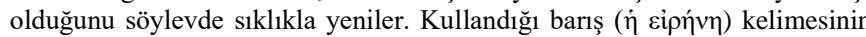
daha önce kullandığı ateşkes, anlaşma ( $\dot{\eta} \sigma \pi 0 v \delta \eta ́)$ kelimesinden farklı olmas da bu olasılı̆̆ 1 güçlendirmektedir.

98 Manuel, durağanlık, değişmezlik için felsefi bir terim olan akinēsia

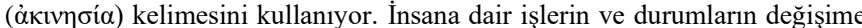

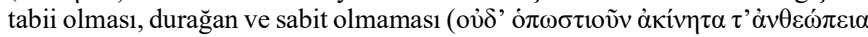

en az diğer uluslar kadar zengin olması da değil. Aksine bunu kazanmasına yardımcı olan o şeylerle, yani büyülerle başardı. ${ }^{96}$ Eğer her şeyi en iyi şekilde idare eden pronoia sayesinde elçilerimiz barış içinde dönseler bile gelecekte barbarların mahvoluşu çabucak gerçekleşebilir. ${ }^{97}$ Çünkü, öncelikle insana dair meseleler değişmeden kalmaz; felsefi bir sözün belirttiği gibi bu meselelerde zihin durağanlık bulamaz. ${ }^{98}$ Ayrıca, bu başımıza gelenler bir nevi tanrısal bir cezalandırmadır; sadece birbirimize karșı olan hatalarımıza karșı değil, ancak bizi yok olandan var eden, O'nun varlığında yaşayıp, hareket edip, var olduğumuz ve yüce Paulos'un da dediği gibi "ruhlarımızı ona emanet edip, ellerine bıraktığımız" Tanrı'ya karșı hatalarımızdan dolayı verilmiş bir cezadır. ${ }^{99}$ Tanrı'nın bize karşı inayetli olup da cezasını kaldırması hiç de imkansız değil; aksine cezasını kaldırınca şüphesiz bizi alışılmış ihsanlarıyla ihya da edecektir. Elbette, nasıl başka türlü olabilir? İnsanlar bile diğer insanlara böyle yapıyor, önceki acıları telafi edecek ve mutluluk getirecek eylemlerde bulunmayı gerekli görüyorlar. O nedenle, eğer bizim elçilerimiz mutabakat ile geri dönerlerse onları sevinçle karşılayalım; onları şimdiki sıkıntılardan bir çıkış sunan kişilerden ziyade adeta gelecekteki iyiliklerin habercileri olarak karşılayalım. ${ }^{100}$ Lakin eğer Tanrı düşmanın kalbini katılaştırırsa - örneğin, bu şekilde kudretini göstereceği için nasıl ki hem firavunun hem kendi kalbini taş gibi kaskatı muhafaza ettiyse - böyle bir durumda inançlı kişilerin olayları insani tasavvurla değerlendirmelerin yakışıksız olduğunu düşünürüm. ${ }^{101}$ Elbette, herkesin kendi üzerine düşeni yerine getirmesi gerekir; Tanrı'nın da beğendiği davranış budur. Yine de her işin sonunu Tanrı'nın ellerine bırakmak gerekir. Zira eğer O istemezse, tüm doğru ve soylu işleri yapsak bile kendimizi koruyamayız, ama zaten gayret gösteren kişiler de terk edilmişlerden değildir. ${ }^{102}$ Buna şahitlik edecek pek çok örnek vardır; mesela tövbelerini gayretle birleştirmiş olan Eriha ve Ninive şehirleri. ${ }^{103}$ Adil Tanrı'nın nazarında her türlü işe gücü yeteceğini bildiğimiz tövbe ${ }^{104}$ hakkında sizlere birkaç hususu hatırlatmak istememe rağmen, dilim iki nedenden ötürü zincirle bağl1. Öncelikle, tövbe şu anki konuşmamızın konusuna değil, başka bir konuşmaya uygun düşecek

$\pi \rho \alpha ́ \gamma \mu \alpha \tau \alpha \ldots .$.$) fikrinin kökenleri Antik Yunan felsefesine dayanır. Manuel,$ diğer eserlerinde de bu fikre değinir.

${ }_{99}$ Resullerin İșleri 17, 28 (Laourdas, s.301) Siyasi ve askeri başarısızlıkların, dışarıdan gelen tehditlerin Tanrı tarafından toplumun günahlarına karşı verilen ceza olması fikrine Bizans eserlerinde (örneğin tarih eserlerinde) sıklıkla rastlanir.

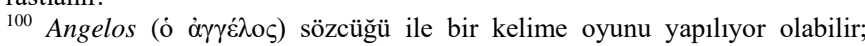
angelos hem haberci hem melek anlamında kullanılırdı. Mutakabat ile dönecek olan elçiler geleceğe dair o kadar iyi haberler getireceklerdir ki adeta vahiy getiren melekler gibi karşılanmalıdırlar.

101 Tanrı'nın işlerine ve altındaki nedenlerle insan aklı her zaman ermez, olaylarda insanın kavrayamayacağı sebepler ve sonuçlar vardır. Yani, Osmanlılar savaşa devam eder ve kuşatmalarında başarılı olmaya devam ederse, Selanikliler bu durum karşısında ümitsizliğe kapılıp, Tanrı'nın onlara yardım etmediğini düşünmemelilerdir. Bu olumsuzluğun altında da Tanrı'nın bir hikmeti olduğunu düșünüp, sabretmelidirler. Manuel, burada firavunun İsrailoğullarını bırakmayı reddetmesini ve Tanrı'nın onun kalbini özellikle katılaştırmasını örnek olarak veriyor. Firavunun Hz Musa'nın tebliğini reddi nedeniyle Tanrı Mısır'a On Bela'yı göndermiştir. (Çıkıș: 7-12) Tanrı'nın firavunun kalbini katılaştırmasının, zulmüne devam etmesine izin vermesinin sebebi kendi ilahi kudretini göstererek, firavunu ağır şekilde cezalandırmaktır.

Manuel'in örnek olarak firavunu seçmesi oldukça anlamlıdır; Selaniklileri esir etmek isteyen Osmanlı sultanını İsrailoğullarını köleleştiren firavunla, Selaniklileri de Tanrı'nın seçilmiş halkı İsrailloğullarıyla eşleştirmiş oluyor.

${ }^{102}$ Tanrı gayret gösterenden yüz çevirmez, onu yalnız bırakmaz.

103 İki şehir de Tanrı'nın gazabına uğramıșladır, ancak sonra tövbe edip Tanrı'nın affına mazhar olmuşlardır, bkz Kitab-1 Mukaddes'deki Tekvin ve Yunus bölümleri. Selaniklilere șehir halkı olarak seslendiği bu söylevde tövbe örneği olarak yine iki şehrin hikayelerini seçmiş olması oldukça yerindedir.

104 Metanoia ( $\dot{\eta} \mu \varepsilon \tau \alpha$ voía) günahlardan duyulan pişmanlık sonucu tövbe durumu anlamına gelen teolojik terim. Manuel, gönülden gelen pișmanlık ve tövbenin Tanrı nazarında tüm günahları silmeye muktedir olabileceğini belirtiyor. 
bir kavram. ${ }^{105}$ Ayrıca, tövbe hakkında konuşmak isteyenlerin önce tövbe haline bürünmeleri gerekir, ancak biz ise bu halden çok uzağız. ${ }^{106}$ Tanrı bize, parlak ve kıymetli şehidinin ${ }^{107}$ şefaatiyle tövbeyi ihsan etsin, tövbemiz nedeniyle de bizlere önce buradaki iyilikleri, sonra da göklerdeki iyilikleri nasip etsin! ${ }^{108}$ Zira tövbenin ardından mutlaka iki cihandaki iyilikler gelecektir, tıpkı bu ilaca ${ }^{109}$ sahip olmayanlar için tam tersi şeylerin geleceği gibi. Sizlerin ise az önce daha detaylıca söylenilen her şeyi yapmanız gerekiyor; savunmaya bonkörce katkıda bulunmanız, gerek halinde sınırsızca para harcamanız, ${ }^{110}$ zorluklara ve tehlikelere aldırmamanız ve ölümü adeta dostunuz, velinimetiniz olarak görmeniz gerekiyor. Bütün bunlara cahil, vahşi hayvanlara benzeyen ve garip yabancı adetlere göre yaşayan barbarlara köle olmamak uğruna katlanmalısınız. Üstelik barbarların, boyunduruğa vurdukları insanları kendi atalarına hakaret etmeye, çocuklarının ve çocuklarının soyunun mahvına zorlayan bu adetlerden zevk duyduğunu biliyoruz. Belki birileri şunu söyleyebilir: bu kadar utanç verici ve acı bir esaretten kaçmak, ruhlarımızı da zarardan korumak $^{111}$ istediğimiz için her çileye katlanmamamız doğru olsa bile, yine de ölüm insan hayatının korkutucu nihayetidir; ölümden kaçmak elzemdir. Lakin şimdi değineceğimiz sebeplerden ötürü ölümü bütünüyle kötü bir șey olarak tasavvur etmemeliyiz. Çünkü, başka pek çok farklı kötülüğün sürekli bir nehir gibi çağıldaması tüm kötülüklerin en beteridir; ölüm ise insana kısacık bir süre acı verir, sonrası rahattır. Yani, ölüm insanın başına gelebilecek en kötü şey değildir. Bu hususta da bize katılan pek çok insan vardır; örneğin buna ben de kesinlikle katılıyorum, barbarların kuşattığı o şehirler de, esaret yerine ölüm için dua eden bütün o insanlar da katılıyor. Ey erkekler, o halde özgürlük uğruna her şeyi yapalım, her şeye göğüs gerelim! Nasıl ki ölüm en kötü şeyse, özgürlüğü de her şeyin en iyisi olarak tasavvur etmelisiniz — tıpk1 az önceki sözlerimizin gayet parlak bir şekilde kanıtladığı gibi. ${ }^{12}$

\footnotetext{
105 Örneğin, tavsiye söylevinden ziyade bir vaaza uygun bir konu.

106 Selanik halkının da tövbe edip, Tanrı'dan af dilemeleri gerektiğini ima ediyor; önceki cümlelerinde kuşatmayı ve Osmanlıların zaferlerini de tanrısal bir ceza olarak tasvir etmişti.

107 Selanik'in koruyucusu Aziz Demetrios.

108 Önce dünyevi yaşamda, sonra ahiretteki iyilikleri.
}

109 İlaç: tövbe.

${ }^{110}$ Sehrin savunmasına finansal katkı beklediğini tekrar vurguluyor.

111 Osmanlılara boyun eğmenin Hristiyanlıklarına halel getireceğini ima ediyor.

112 'gayet parlak bir şekilde': Manuel, üstü kapalı bir şekilde kendi söylevini ve argümanlarını övüyor. 


\section{KAYNAKÇA}

\section{Birincil Kaynaklar}

Chalkokondyles, Laonikos. The Histories, ed. ve çev. Anthony Kaldellis, Harvard University Press, Cambridge MA ve Londra, 2014.

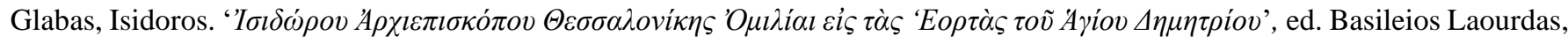

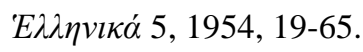

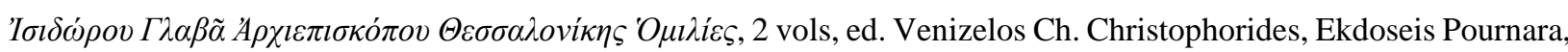
Selanik, 1992-1996.

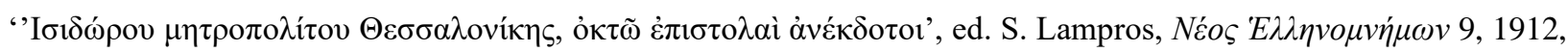
ss. $343-414$.

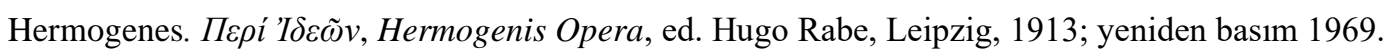

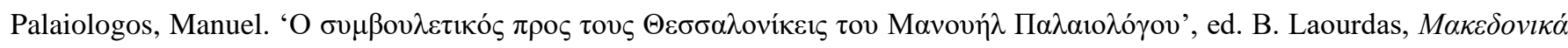
3, 1955, ss. 290-307.

Dialoge mit einem Perser, ed. Erich Trapp, Österreichische Akademie der Wissenschaften, Viyana, 1966.

Dialoge mit einem Muslim, 3 vols, ed. ve çev. Karl Förstel, Echter-Oros Verlag, Würzburg, 1995.

Funeral Oration to His Brother Theodore, ed. ve çev. Julian Chrysostomides, Association for Byzantine Research,

Selanik, 1985.

The Letters of Manuel II Palaeologus, ed. ve çev. George T. Dennis, Dumbarton Oaks Reseach Library and Collection, Washington DC, 1977.

Kydones, Demetrios. Démétrius Cydonès Correspondance, 2 vols, ed. Raymond Joseph Loenertz, Biblioteca Apostolica Vaticana, Roma, Vatikan, 1951-1960.

Thiriet, Freddy. Régestes des délibérations du sénat de Venise concernant la Romanie, 3 vol, Paris Le Haye, Mouton et co, Paris, 1958.

\section{İkincil Kaynaklar}

Angelov, Dimiter. G. 'Three kinds of liberty as political ideals in Byzantium, twelfth to fifteenth century', Proceedings of the $22^{\text {nd }}$ International Congress of Byzantine Studies, I: Plenary Sessions, Sofya, 2011, ss. 311-331.

Balivet, Michel. 'Le soufi et le basileus: Haci Bayram Veli et Manuel II Paléologue', Medievo Graeco 4, 2004 , ss. 19-31.

Barker, John W. Manuel II Palaeologus (1391-1425): A Study in Late Byzantine Statesmanship, Rutgers University Press, New Brunswick, 1969.

'Late Byzantine Thessalonike: a second city’s challenges and responses', Dumbarton Oaks Papers, 57, 2003), ss. $5-30$.

Çelik, Siren. 'The emperor, the sultan and the scholar: the portrayal of the Ottomans in the Dialogue with a Persian of Manuel II Palaiologos', Byzantine and Modern Greek Studies 412 (2017), ss. 208-228. Manuel II Palaiologos (1350-1425): A Byzantine Emperor in a Time of Tumult, Cambridge University Press, New York, 2021.

Dennis, George. T. The Reign of Manuel II Palaeologus in Thessalonica (1382-1387), Pontificum Institutum Orienatalium Studiorum, Roma, 1960.

Dölger, Franz. 'Zum Aufstand des Andronikos IV gegen seinen Vater Johannes V im Mai 1373', Revue des Etudes Byzantins 19, 1961, ss. 328-333. 
Elam, Nilgün. 'Babalar ve Oğullar: IV. Andronikos Palaiologos ve Savcı Çelebi’nin isyanı (1373)', Tarih Araştırmaları Dergisi 30, 2011, ss. 29-74.

İnalcık, Halil. 'Ottoman methods of conquest', Studia Islamica 2, 1954, ss. 108-129.

Kafadar, Cemal. Between Two Worlds: The Construction of the Ottoman State, University of California Press, Berkeley ve Los Angeles, 1996.

Karathanassis, Athanasios. 'Philip and Alexander of Macedon in the literature of the Palaiologan era', Byzantine Macedonia, Identity, Image and History (ed. John Burke - R. Scott), Brill, Melbourne, 2000, ss. 111-115.

Kyritses, Demetrios. 'The Imperial council in Byzantium and the tradition of consultative decision-making in Byzantium', Power and Subverison in Byzantium, Papers from the $43^{\text {rd }}$ Spring Symposium of Byzantine Studies, Birmingham, March 2010 (ed. Dimiter Angelov ve Michael Saxby), Ashgate, Farnham, 2013, ss. 57 - 67.

Loenertz, Raymond Joseph. 'La première insurrection d'Andronic IV Paléologue (1373)', Echos d'Orient 38, 1939 , ss. 334-345. Lowry, Heath, W. The Nature of the Early Ottoman State, State University of New York Press, Albany, 2003.

Macrides, Ruth J. 'Subversion and loyalty in the cult of Saint Demetrios', Byzantinoslavica 51, 1990, ss. 189-197.

Necipoğlu, Nevra. 'The aristocracy in late Byzantine Thessalonike: a case study of the City's archontes (late 14th and early 15th centuries)', Dumbarton Oaks Papers 57, 2003, ss. 133-151.

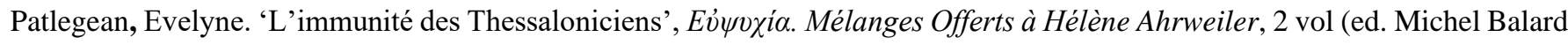
et al), Publications de la Sorbonne, Paris, 1998, ss. 591-601.

Tsirpanlis, Constantine N. 'Byzantine parliaments and representative assemblies from 1081 to 1351', Byzantion 43, 1973, ss. $432-483$. 


\section{EXTENDED ABSTRACT}

This article offers a Turkish translation of the Advisory Discourse to the Thessalonians of the Byzantine Emperor Manuel II Palaiologos (13501425 ) into Turkish and the first in-depth study of the oration. While governing Thessalonike between 1383-1387 independently from his father John V Manuel refused his father's policy of reconciliation towards the Ottomans and instead, entered into military conflicts with them. As an outcome of Manuel's policy, Thessalonike was besieged in 1383 on the orders of the Ottoman Sultan Murad I. Manuel wrote and performed the Advisory Discourse to the Thessalonians in order to persuade Thessalonians to fight aganist the Ottomans, targeting particularly those citizens who inclined towards surrendering and paying tribute to the Ottomans. The oration, composed in rather difficult Attic Greek is understudied, yet it is noteworthy on the account of the historical information it offers, as well of its literary aspects. The oration, composed in a rather difficult Attic Greek is understudied, yet it is noteworthy on the account of the historical information it offers, as well of its literary aspects. The oration can still be accessed only in the original Greek, and as far as we know, it has not yet been translated. While it exhibits stylistic influences of Demosthenes, the oration also draws from other classical authors and biblical sources. Moreover, Manuel also incorporates notions from Aristotelian ethics into his oration. As his chief theme, Manuel argues that the Ottomans do not merely desire tribute, but to eventually master the city itself. Stressing the importance of financially contributing to the defence of the city, Manuel presents his audience with a choice between death and freedom, between living as slaves and living as free, virtuous Christians. In order to appeal to its audience, the oration highlights elements of Thessalonian civic idenitity such as Saint Demetrios and its Hellenic past. The Christian identity of Byzantine Thessalonike also plays a significant role. The Ottomans are portrayed as infidels and enemies of Christ, while the Thessalonians are charged with the duty of dying in order to defend their Christianity. Manuel also offers several hints as to the unwillingness of the citizens to defend their city and resist the Ottomans. He points out that many were in favour of surrendering to the Ottomans and even opposed the convocation of an assembly. Futhermore, the oration is laced with appeals for financial contributions from the citizens and chastisement for their lack of generousity. All in all, Advisory Discourse to the Thessalonians is a significant historical source shedding light on the Ottoman siege of Thessalonike, as well as displaying arresting literary aspects. 